\title{
THE EVOLUTION OF THE CRUSTAL STRESS STATE OF THE CATOCA KIMBERLITE PIPE AREA (NORTHEASTERN ANGOLA)
}

\author{
0. V. Lunina1, A. S. Gladkov1, D. P. Gladkochub¹, F. João², M. A. Karpenko², \\ J. T. Félix², D. A. Koshkarev³, E. V. Sklyarov \\ ${ }^{1}$ Institute of the Earth's Crust, Siberian Branch of RAS, Irkutsk, Russia \\ 2 Sociedade Mineira de Catoca (Catoca Ltd.), Luanda, Angola \\ ${ }^{3}$ Geological Enterprise of Exploration, Public Joint Stock Company «ALROSA», Mirny, Russia
}

\begin{abstract}
This paper presents the first results of the geostructural and tectonophysical studies of the crustal stress state in the Catoca kimberlite pipe area at the southwestern flank of the Kasai Shield in the northeastern Angola. In the evolution of the crustal stress state, six main stages are distinguished by analyzing the displacements of markers, fold hinges, long axes of boudins, granite dikes of various intrusion phases and kimberlites, as well as fractures with striations. For each of these stages, a dominating horizontal tectonic stress and its orientation is identified. During stage 1 (NW extension and shearing) and at the beginning of stage 2 (NW compression), structures formed in the host rocks in brittle-plastic conditions. The replacement of plastic deformation by faulting could occur about 530-510 Ma ago, when the continental crust of Africa had completely formed. Stage 3 (radial, mainly NW extension) and stage 4 (shearing, NW extension, and NE compression) were the most important for kimberlite occurrence: in the Early Cretaceous, radial extension was replaced by shearing. Both stages are related to opening of the central segment of the South Atlantic. The main kimberlite magmas occurred during the break-up of the Angola-Brazilian segment of Gondwana. In the course of all the four stages, stress was mainly released by the NE- and E-NE-striking faults and, to a lesser extent, by the NW-striking and latitudinal faults. The initial stage of kimberlite magmatism is associated with the NE- and E-NE-striking faults due to the presence of the Precambrian zones of flow and schistosity, which facilitated the NW-trending subhorizontal extension. Stage 5 (NE compression) began in the second half of the Cretaceous and possibly lasted until the end of the Paleogene, and compression occurred mainly along the NW-striking faults. Regionally, it corresponds to two stages of inversion movements in the southern regions of Africa, during which the Angola dome-shaped uplift emerged and the shoulders of the East African rifts began to take shape. Stage 6 (horizontal extension, mainly in the N-NE direction) is related to the processes that took place in the southern segment of the Tanganyika rift and the eastern coast of the Atlantic. Based on the results of our studies, it became for the first time possible to get an idea of the main stages in the evolution of the studied region. Further geostructural measurements and dating of the host rocks will provide for a more precise definition of the proposed stages.
\end{abstract}

Key words: stress field; fracturing; fault; dike; fold; striation; stage; kimberlite; Catoca; northeast of Angola

\section{RESEARCH ARTICLE}

Handling Editor: K.Zh. Seminsky
Received: March 14, 2018

Revised: May 31, 2018

Accepted: June 4, 2018

For citation: Lunina O.V., Gladkov A.S., Gladkochub D.P., João F., Karpenko M.A., Félix J.T., Koshkarev D.A., Sklyarov E.V., 2018. The evolution of the crustal stress state of the Catoca kimberlite pipe area (northeastern Angola). Geodynamics \& Tectonophysics 9 (3), 827-854. doi: 10.5800/GT-2018-9-3-0373.

Для цитирования: Лунина О.В., Гладков А.С., Гладкочуб Д.П., Жоао Ф., Карпенко М.А., Феликс Ж.Т., Кошкарев Д.А., Скляров Е.В. Эволюция напряженного состояния земной коры района кимберлитовой трубки Катока, северо-восток Анголы// Геодинамика и тектонофизика. 2018. T. 9. № 3. С. 827-854. doi:10.5800/GT-2018-9-3-0373. 


\title{
ЭВОЛЮЦИЯ НАПРЯЖЕННОГО СОСТОЯНИЯ ЗЕМНОЙ КОРЫ РАЙОНА КИМБЕРЛИТОВОЙ ТРУБКИ КАТОКА, СЕВЕРО-ВОСТОК АНГОЛЫ
}

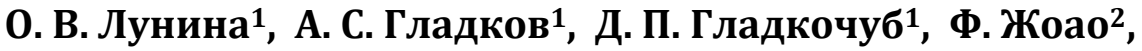 \\ М. А. Карпенкоㄹ, Ж. Т. Феликс ${ }^{2}$, Д. А. Кошкарев ${ }^{3}$, Е. В. Скляров ${ }^{1}$ \\ ${ }^{1}$ Институт земной коры СО РАН, Иркутск, Россия \\ ${ }^{2}$ Горнорудное общество Катока (Катока Лтд.), Луанда, Ангола \\ ${ }^{3}$ Научно-исследовательское геологоразведочное предприятие АК «АЛРОСА» (ПАО), Мирный, Россия
}

\begin{abstract}
Аннотация: В статье представлены первые результаты геолого-структурного и тектонофизического изучения напряженного состояния земной коры района алмазоносной трубки Катока, расположенной на югозападном фланге щита Касаи на северо-востоке Анголы. На основе анализа смещений маркеров, шарниров складок и длинных осей будин, даек гранитов различных фаз внедрения и кимберлитов, а также трещин со штрихами скольжения выделено шесть основных этапов в эволюции напряженного состояния земной коры. Эти этапы обусловлены доминированием ориентированных в определенном направлении горизонтальных тектонических напряжений сжатия и/или растяжения, господствовавших в течение всей истории тектонического развития региона. В ходе первого этапа - превалирующего северо-западного растяжения со сдвигом - и начала второго этапа - северо-западного сжатия - формирование структур во вмещающих породах происходило в хрупкопластических условиях. Смена пластических деформаций на разрывные могла произойти примерно 530-510 млн лет назад, когда континентальная кора Африки была окончательно сформирована. Третий и четвертый этапы, важнейшие для кимберлитообразования, в течение которых в раннем мелу радиальное растяжение сменилось сдвиговым полем напряжений, характеризуются превалированием северо-западного растяжения. Оба этапа связаны с открытием центрального сегмента Южной Атлантики, а основной кимберлитовый магматизм приходится на момент разрыва Анголо-Бразильского сегмента Гондваны. В ходе всех четырех этапов разрядка напряжений происходила в основном по разрывным нарушениям северо-восточного и восток-северо-восточного простирания, в меньшей степени северо-западного и широтного. Начальный этап кимберлитового магматизма связан с разрывами двух первых указанных направлений, что предопределено наличием древних докембрийских зон течения и рассланцевания, которые оказались наиболее благоприятными для реализации северо-западного субгоризонтального растяжения. Последующее северовосточное сжатие (пятый этап), начавшееся во второй половине мела и, возможно, продлившееся до конца палеогена, реализовалось в основном по разрывам северо-западного простирания. В региональном отношении ему соответствуют два этапа инверсионных движений на юге Африке, в ходе которых возникло Ангольское куполовидное поднятие и началось формирование плеч Восточно-Африканских рифтов. Последний этап горизонтального растяжения в доминирующем север-северо-восточном направлении связан с процессами, происходящими на юге Танганьикского рифта и восточном побережье Атлантики. Результаты исследований впервые позволили получить представление об основных этапах развития региона, которые впоследствии будут уточняться на основании большего количества геолого-структурных измерений и данных датирования вмещающих пород.
\end{abstract}

Ключевые слова: поле напряжений; трещиноватость; разлом; дайка; складка; штрихи скольжения; этап; кимберлит; Катока; северо-восток Анголы

\section{1. ВВЕДЕНИЕ}

Изучение эволюции напряженного состояния земной коры является принципиально важным для выделения этапов становления, активизации и развития разломов, вмещающих месторождения полезных ископаемых, в том числе алмазов. Подобные исследования необходимы для расшифровки структурных признаков локализации кимберлитовых тел и безопасного ведения горных работ [Gladkov et al., 2010, 2016]. В свою очередь, вскрытие земной поверхности карьером позволяет эффективно исследовать в одном локальном месте раз- новозрастные хрупкие и пластические деформации, которые хранят в себе историю тектонического развития крупных регионов. Это особенно важно для слабообнаженных территорий, каким в своей большей части является Африканский континент.

Исследования напряженного состояния земной коры Африки касаются в основном Восточно-Африканской рифтовой системы [Delvaux, 2001; Delvaux, Barth, 2010], северной части Африки [Soumaya et al., 2015; Bosworth, 2008], а также юго-западной окраины континента в пределах Намибии и ЮАР [Bird et al., 2006]. Большинство стресс-тензоров получены 


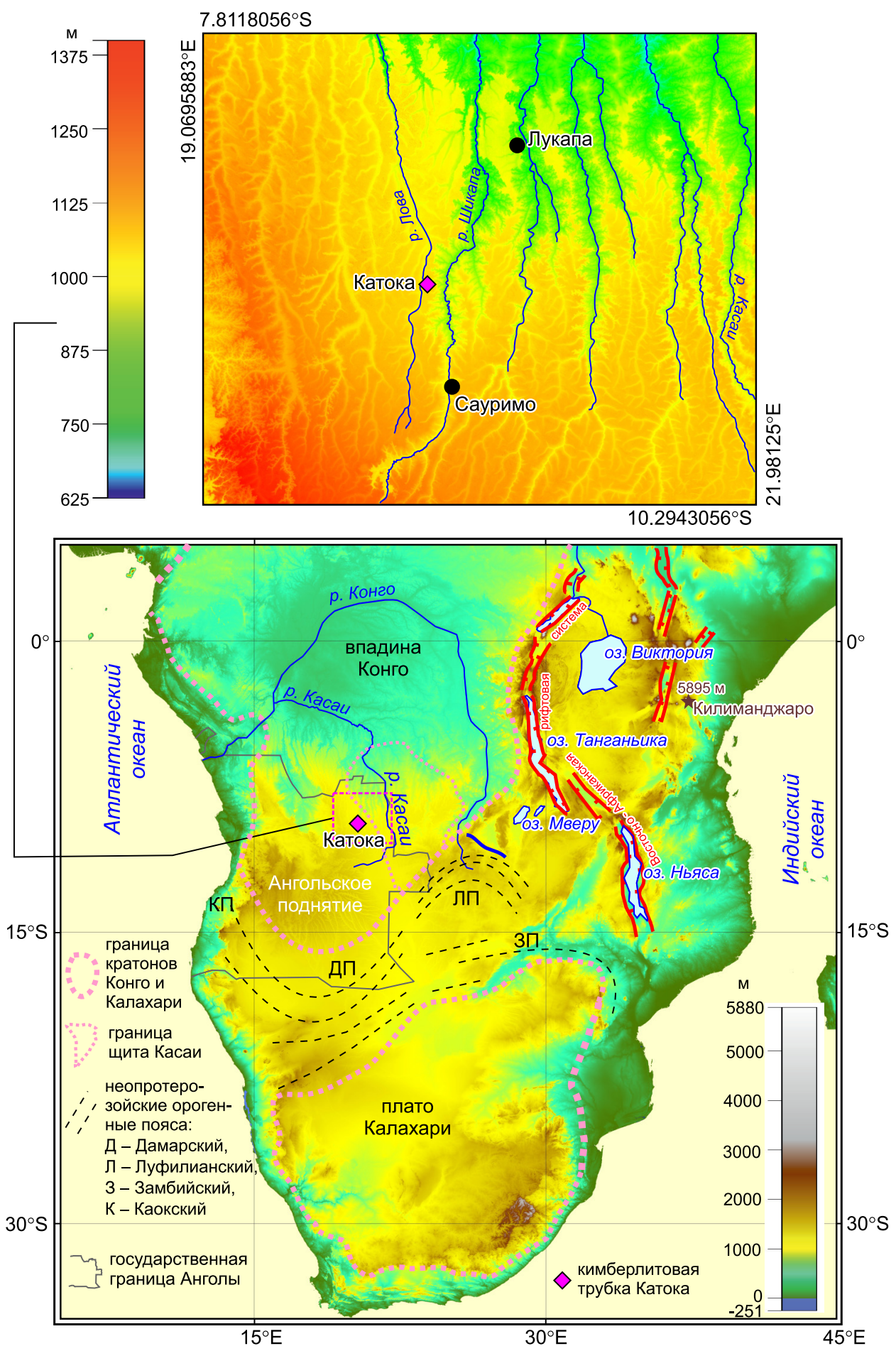

Рис. 1. Расположение трубки Катока и основных физико-географических и тектонических единиц, упоминаемых в тексте.

Fig. 1. Locations of the Catoca kimberlite pipe area and the main units of physical geography and tectonics mentioned in the text.

из анализа механизмов очагов землетрясений и характеризуют современное поле напряжений $[M e-$ ghraoui et al., 2016]. Основательный анализ трещин со штрихами был проведен только для Луфилианской складчатой дуги и ее предгорий [Kipata et al., 2013], где авторы цитируемой работы выделили в эволюции напряженного состояния земной коры восемь основных этапов, характеризующих период $\sim 550$ млн лет.

В апреле 2017 г. на карьере «КАТОКА», расположенном на северо-востоке Анголы (рис. 1), авторами были получены уникальные геолого-структур- 
ные данные, в том числе по смещениям маркеров, шарнирам складок и длинным осям будин, дайкам гранитов различных фаз внедрения и кимберлитов, а также по трещинам со штрихами скольжения. Разнообразие линейно-ориентированных структурных элементов, измеренных в разновозрастных горных породах, даже при небольшом количестве полученных замеров позволило реконструировать стресс-тензоры и наметить основные этапы эволюции напряженного состояния участка земной коры, в котором локализуется крупнейшая алмазоносная трубка Катока. В настоящей статье мы представляем первые результаты этих исследований, включающие также определение порядка проявления во времени полей напряжений с выделением благоприятной обстановки для внедрения кимберлитов и оценку влияния тектонических процессов на юге Африки на геодинамический режим эволюции платформенной территории, расположенной в сотнях километрах от подвижных поясов.

\section{2. ТЕКТОНИЧЕСКАЯ ПОЗИЦИЯ, МОРФОЛОГИЯ И ГЕОЛОГИЧЕСКОЕ СТРОЕНИЕ МЕСТОРОЖДЕНИЯ КАТОКА}

\section{1. ТЕКТОНИЧЕСКАЯ ПОЗИЦИЯ МЕСТОРОЖДЕНИЯ}

Кимберлитовая трубка Катока приурочена к юго-западной части щита Касаи, который представляет собой одно из двух поднятий крупнейшего в регионе архей-нижнепротерозойского кратона Конго (рис. 1). В орографическом плане территория района представляет собой монотонную равнину восточную часть плато Лунда с общим наклоном поверхности в направлении с юга на север, с абсолютными отметками от 1078 до 1036 м на водоразделах и от 1000 до 900 м в долинах рек. Площадь на большей части перекрыта отложениями платформенного чехла. Породы фундамента обнажаются в долинах рек, вытянутых в меридиональном направлении и принадлежащих бассейну р. Конго. Месторождение Катока находится на правом склоне долины р. Лова, одного из левых притоков р. Шикапа, в естественной эрозионной котловине (рис. 1). До мелового периода геологические образования для этого района, за исключением архейских пород фундамента, неизвестны.

Многочисленные кимберлитовые поля раннемелового возраста приурочены к региональной зоне глубинных разломов, именуемой в литературе «коридором Лукапа» и ассоциируемой с авлакогеном [Reis, 1972; De Boorder, 1982; Araujo et al., 1992; White et al., 1995; Zinchenko, 2015] (рис. 2). Система этих нарушений шириной 55-100 км простирается от берегов Атлантического океана в северо-восточном направлении на 1400 км. Внутри «коридора Лукапа», в пределах провинции Лунда Сул, где расположена трубка Катока, главные кимберлитовые поля локализуются в областях доминирования второстепенных разрывных нарушений востоксеверо-восточного простирания [White et al., 1995] (рис. 2, a).

По иным представлениям, кимберлитовые трубки в пределах «коридора Лукапа» локализованы в узлах пересечения двух систем глубинных разломов северо-восточного и северо-западного направлений, приуроченных к центрам кольцевых структур, выделяемых по данным дешифрирования космических снимков и обработки аэрогеофизических съемок [Serokurov, Kalmykov, 2004; Serokurov, 2006], а также наземной магнито- и электроразведки [Zinchenko et al., 2011]. В частности, поле Катока находится в центре кольцевой структуры диаметром 40 км (рис. 2, б), а на локальном уровне - в центре кольцевой структуры диаметром 4 км, по периметру которой расположены десять более мелких трубок спутников. На СВ фланге «коридор» Лукапа пересекает «коридор» Кванго, предположительно одновозрастный с ним по времени заложения и тектонического развития [Zinchenko, 2015].

\section{2. МОРФОЛОГИЯ ТРУБКИ И ГЕОЛОГИЧЕСКОЕ СТРОЕНИЕ МЕСТОРОЖДЕНИЯ}

Трубка Катока, представляющая собой слабоэродированный полеовулкан, входит в число крупнейших кимберлитовых месторождений мира по размерам и разведанным запасам алмазов [Zinchen$k o, 2015]$. До начала отработки ее длина и ширина в плане составляли 990 и 915 м, соответственно. В вертикальном разрезе рудное тело представлено в виде воронки, верхняя часть которой является типичным кратером (рис. 3). Поверхность жерла в общих чертах повторяет форму поверхности трубки, а ее размеры в плане составляют $550 \times 520$ м. С глубиной площадь поперечного сечения уменьшается. Падение контактов рудного тела с вмещающими породами направлено к центру и изменяется в весьма широких пределах.

Вмещающие кимберлитовую трубку породы архейского возраста представлены в разной степени мигматизированными биотитовыми, биотит-амфиболовыми, амфиболовыми гнейсами, амфиболитами и горнблендитами. Судя по отсутствию крупнозернистых разновидностей и реликтов интрузивных структур и текстур, протолитом гнейсов были вулканиты дифференцированной серии от дацитов (биотитовые гнейсы) до меланобазальтов (горнблендиты). Мигматизация проявлена по-разному в 
(a)

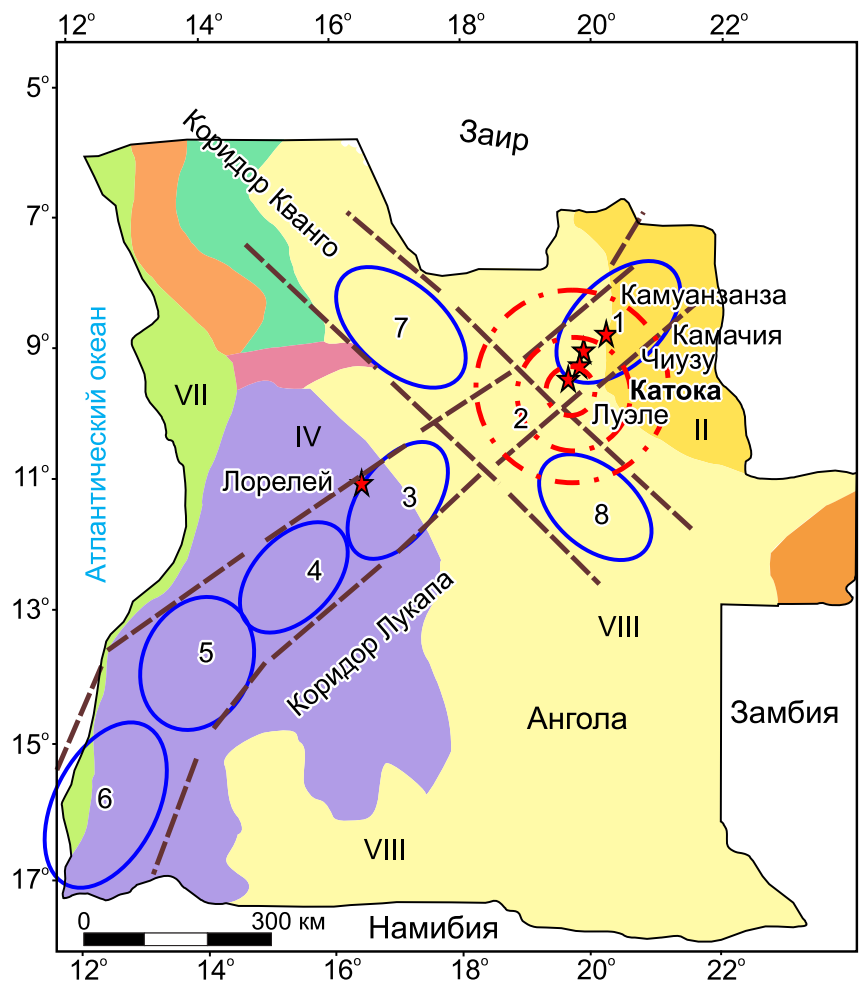

AR щиты: II - Касаи, IV - Ангольский; периокеанические впадины: VII - Кванза; континентальные впадины: VIII - Конго-Окаванго; кимберлитовые районы (клаймы): 1 - Лунда, 2-Кукумби, 3 -Кванза, 4 - Лонга, 5 - Катумбела, 6 - Кунене, 7 - Кванго, 8 - Калахари; границы коридоров (авлакогенов) Лукапа и Кванго обозначены коричневой пунктирной линией; месторождения кимберлитов обозначены звездочкой; кольцевые разломы Сауримской региональной структуры-красные линии. (б)
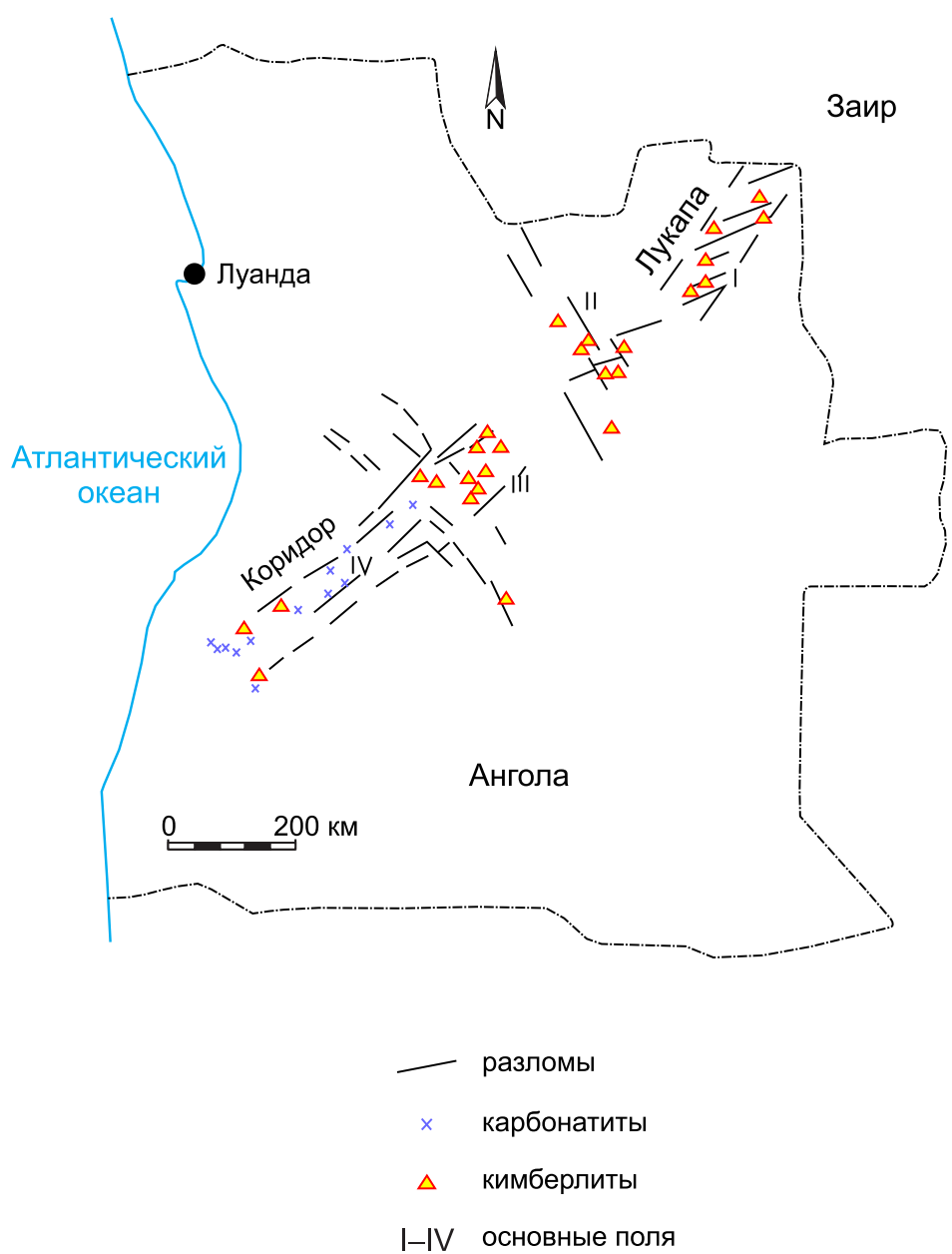

Рис. 2. Тектоническая позиция кимберлитовых районов (провинций) и трубок Анголы в пределах «коридора» Лукапа по данным разных авторов: (a) - по [Araujo et al., 1998; Mankenda, 1989; Vunda, 2010; Zinchenko, 2015]; (б) - по [Reis, 1972; De Boorder, 1982; Whiteetal., 1995].

Fig. 2. Tectonic positions of kimberlite provinces and pipes within the Lucapa 'corridor' in Angola: (a) after [Araujo et al., 1998; Mankenda, 1989; Vunda, 2010; Zinchenko, 2015]; (б) after [Reis, 1972; De Boorder, 1982; White et al., 1995].

северной и южной части карьера. Для северной части характерны артериты (послойные мигматиты) и инъекционные (линзовидно-полосчатые) мигматиты. В южной части распространены агматиты (брекчиевидные мигматиты) и небулиты (теневые мигматиты), вплоть до появления анатектических гранитов. Лейкосома в мигматизированных гнейсах и амфиболитах нередко подчеркивает изоклинальную складчатость толщи, несмотря на внешне массивный облик пород. Иногда встречаются птигматитовые складки на фоне линейного характера лейкократовых прожилков (рис. 4, a).

На следующем этапе процесса мигматизации внедрились конформные гнейсовидности жилы гранитов мощностью до 1 м (рис. 4, б). В переходной зоне, разделяющей разные типы мигматитов (артериты - агматиты), появились еще более круп- ные, согласные первичной мигматитовой полосчатости, дайки гранитов мощностью от 20 до 50 м (рис. 4,8$).$ За этим последовали секущие интрузии ультраосновных пород (горнблендитов) (рис. 4, г). Самыми поздними являются жилы гранитов (мощность до 1 м), имеющие разную ориентировку и характеризующиеся пологим падением (рис. 4, д). Граниты представлены в основном плагиоразностями, но иногда встречаются и двуполевошпатовые.

Вмещающие породы значительно деформированы. В них наблюдаются складки, будины, зоны течения, рассланцевания, милонитизации, дробления и трещиноватости, образовавшиеся и активизированные в различные периоды развития земной коры. Преобладающие азимуты падения гнейсовидности $330-350^{\circ}$, углы падения - 60-80 (рис. 5). 

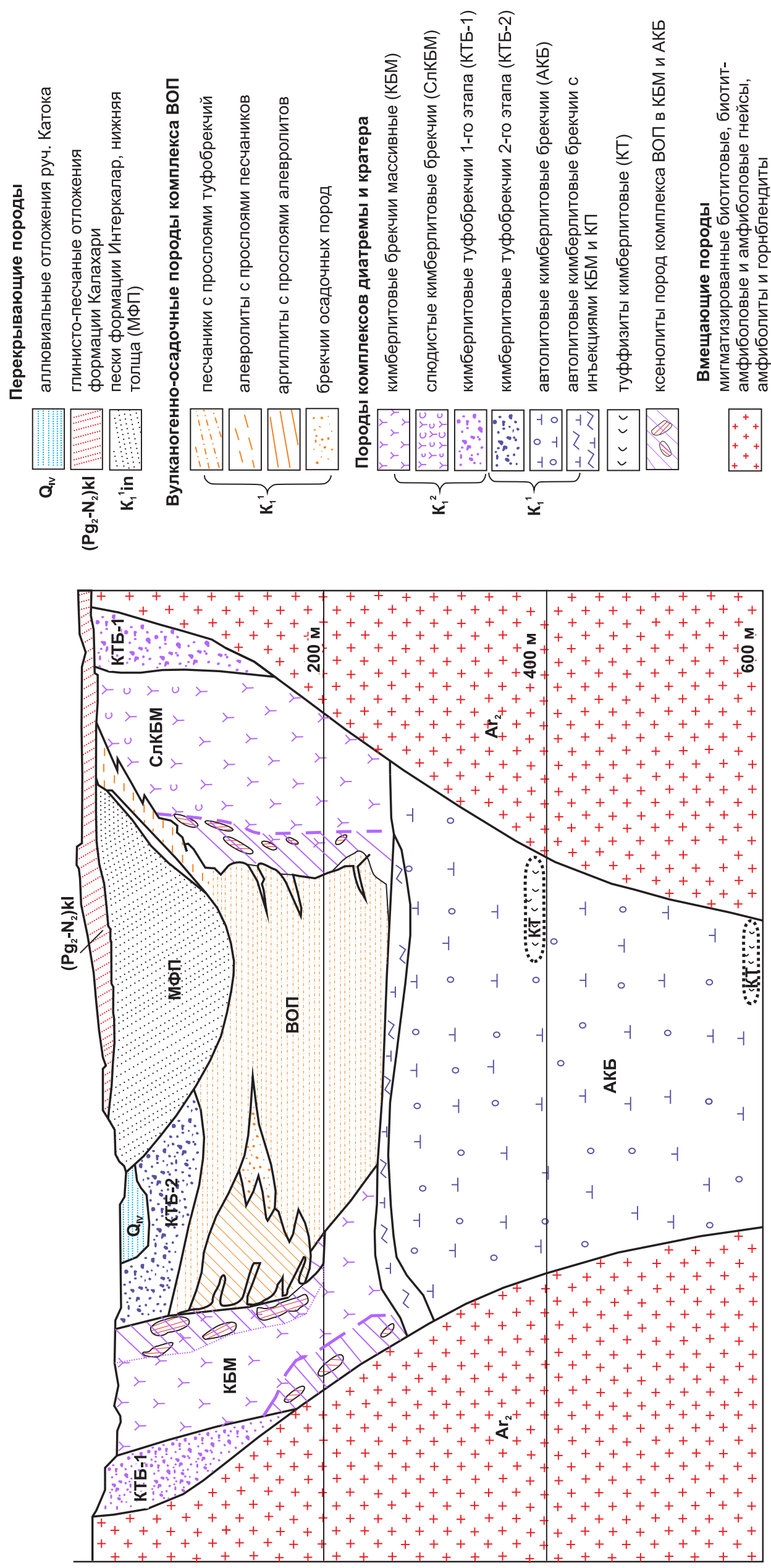
(a)

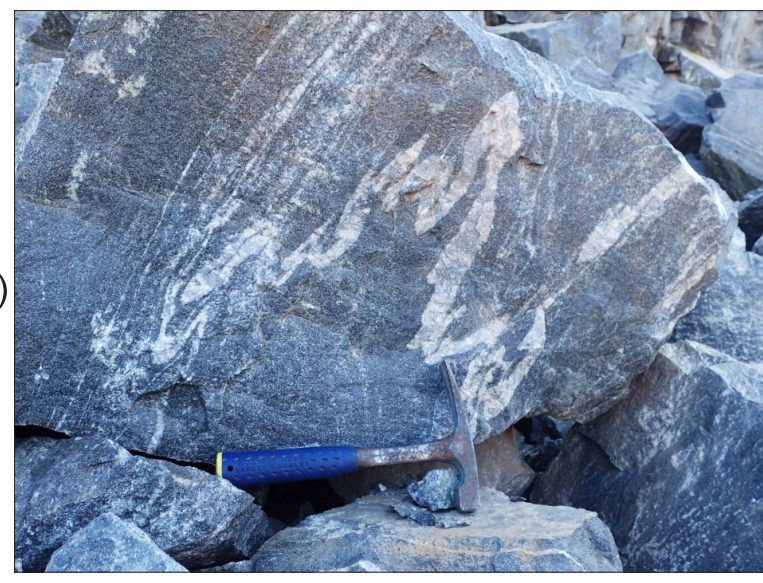

(8)

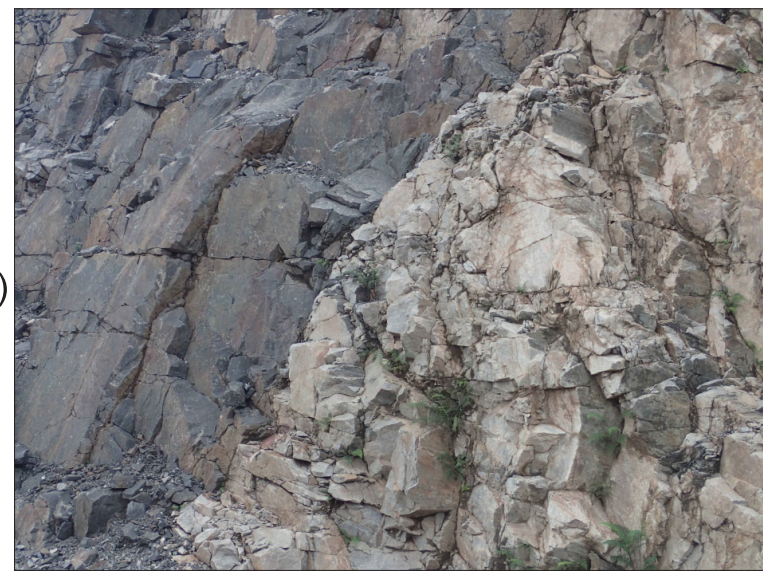

(d)

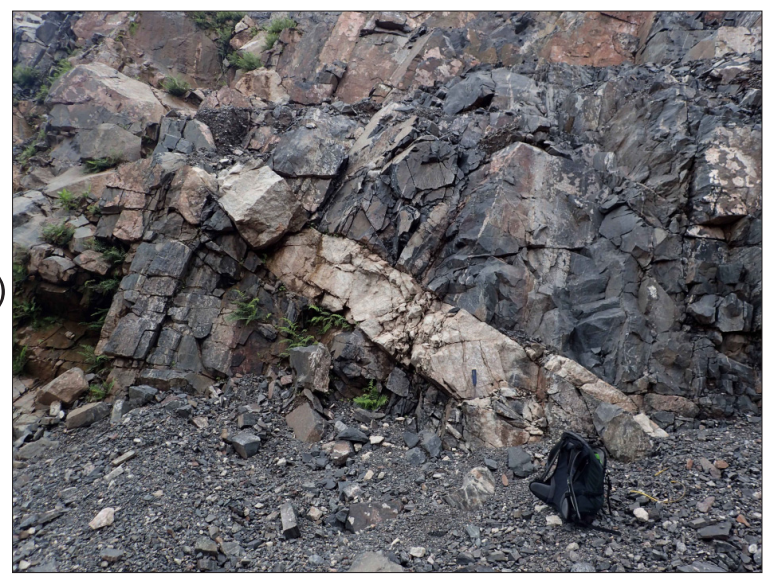

(б)

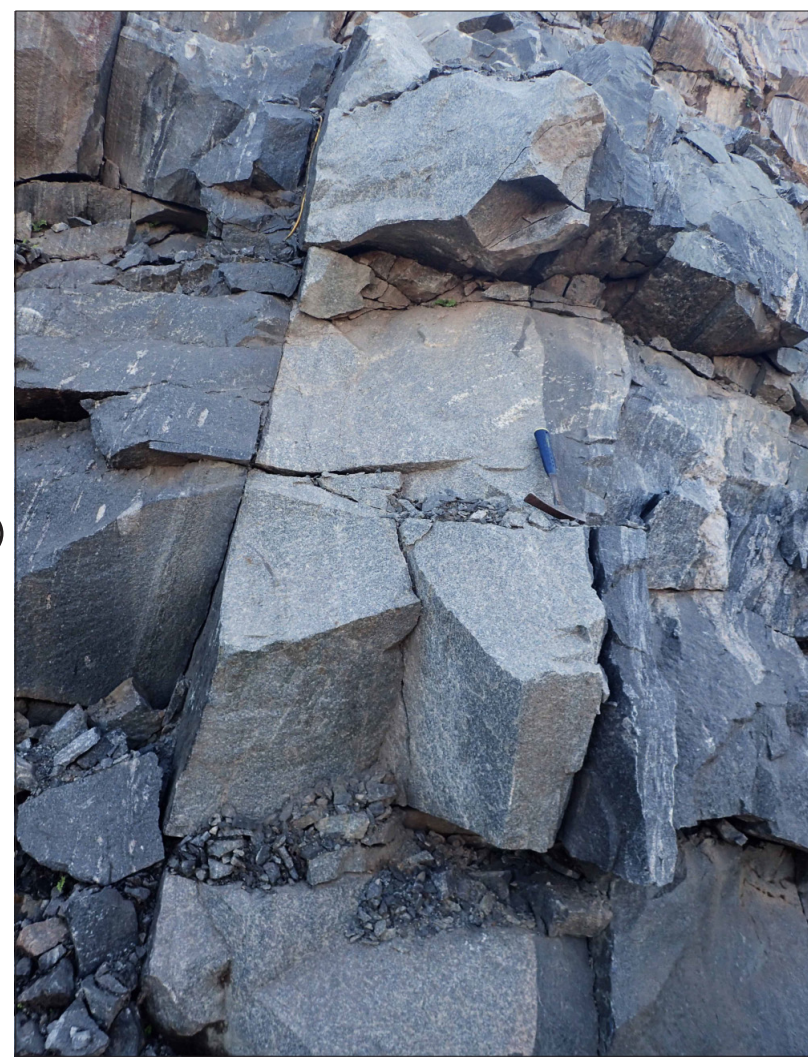

(2)

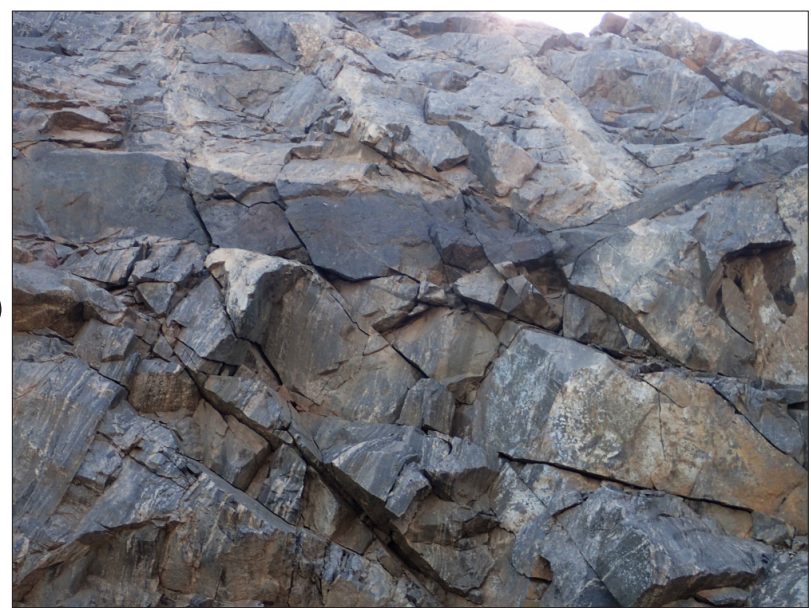

Рис. 4. Проявление мигматизации во вмещающих кимберлитовую трубку породах: $(a)$ - птигматитовые жилки в амфиболовых меланократовых гнейсах; (б) - конформная жила амфиболовых гранитов в мигматизированных амфиболовых гнейсах; (8) - мощная (30 м) конформная жила гранитов в мигматизированных амфиболитах; (2) - пологопадающая дайка горнблендитов, секущая мигматизированные биотит-амфиболовые меланократовые гнейсы; $(\partial)$ - наиболее поздняя секущая гранитная жила в мигматизированных биотит-амфиболовых гнейсах.

Fig. 4. Migmatization in the rocks enclosing the kimberlite pipe: $(a)$ - ptigmatitic veins in amphibole melanocratic gneiss; (б) - conformal vein of amphibole granite in migmatized amphibole gneiss; $(8)$ - thick $(30 \mathrm{~m})$ conformal vein of granite in migmatized amphibolite; (2) - low-angle hornblendite dike cutting across migmatized biotite-amphibole melanocratic gneiss; $(\partial)$ - the most recent granite vein cutting across migmatized biotite-amphibole gneiss.

Рудное тело в жерловой части представлено породами комплекса АКБ - автолитовых кимберлитовых брекчий, которые пока вскрыты только скважинами. Хорошо сохранившийся кратер сло- жен полигенными комплексами пород кимберлитовой формации, различными по вещественному составу и петрофизическим свойствам [Zinchenko, 2015]. Среди основных выделяют вулканогенно- 
(a)

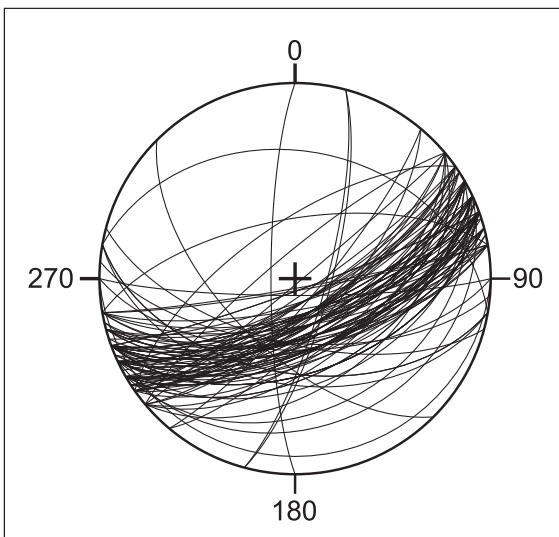

(б)

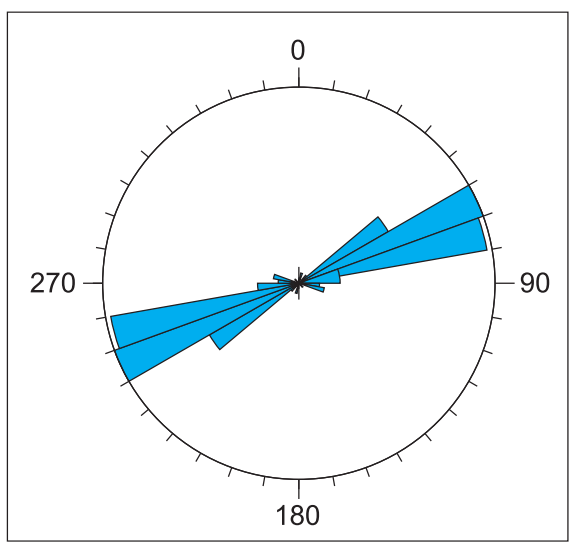

(в)

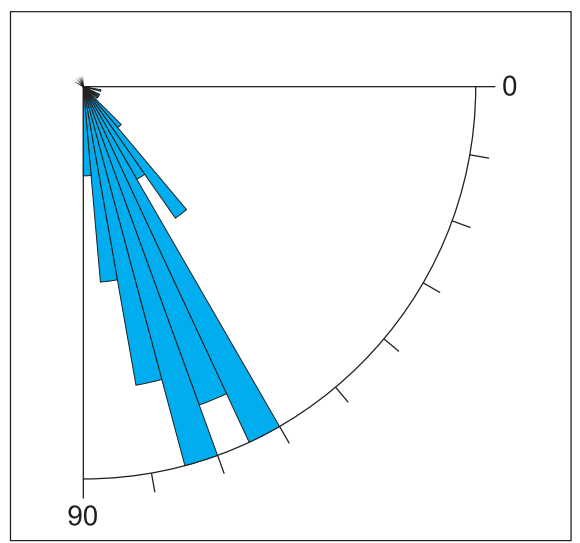

Рис. 5. Элементы залегания гнейсовидности вмещающих кимберлитовую трубку пород: $(a)$ - в проекции верхней полусферы, (б) - на роза-диаграммах азимутов простирания и (в) - углов падений. Количество замеров 118.

Fig. 5. Dip and strike of gneissosity in the rocks enclosing the Catoca kimberlite pipe: $(a)$ - projection of the upper hemisphere; (б) - rose-diagram of strike azimuths; $(в)$ - rose-diagram of dip angles. Number of measurements: 118.

осадочные внутрикратерные образования комплекса вулканогенно-осадочных пород (ВОП), массивные и слюдистые кимберлитовые брекчии (КБМ и СлКБМ), а также кимберлитовые туфобрекчии 1-го и 2-го этапа (КТБ-1 и КТБ-2). Кроме того, в диатреме и кратере описывают кимберлиты зоны перехода (КЗП), брекчии «ксенолитового слоя» (БКС), дайки порфировых кимберлитов (КП), приконтактовые ксенолитовые брекчии (ПКБ) и кимберлитовые туффизиты (КТ), имеющие значительно меньшее распространение по сравнению с основными петрогенетическими комплексами (Ganga et al., 2003; Zinchenko et al., 2006; Zinchenko, 2015). Возраст кимберлитов трубки Катока оценивается в 118.3 \pm 3.7 млн лет [Robles-Cruz et al., 2010], что соответствует аптскому ярусу нижнего мела.

Перекрывающими породами являются палеогеннеогеновые песчаники формации Калахари мощностью до 40 м и нижнемеловые песчаники формации Интеркалар мощностью до 140 м [Zinchenko, 2015].

\section{3. МЕТОДЫ СБОРА И ОБРАБОТКИ ГЕОЛОГО-СТРУКТУРНОЙ ИНФОРМАЦИИ}

В пределах горизонтов карьера «Катока» (от абс. отм. +825 до +925) в апреле 2017 г. было создано 149 точек геолого-структурных наблюдений (рис. 6). Точка наблюдения (т.н.) представляла собой отрезок горной выработки протяженностью от 5 до 15 м, в пределах которого проводился комплекс измерений тектонических нарушений.

Наблюдения начинались с привязки т.н. на плане выработки, описания ориентировки и раз- меров выхода, типа слагающих его пород и элементов залегания гнейсовидности или полосчатости/слоистости. Затем выделялись основные системы трещин, документировались взаимоотношения разрывов различных систем друг с другом. Далее проводилось изучение дизъюнктивных структур более крупного по отношению к трещинам масштаба (зон трещиноватости, рассланцевания, дробления и/или милонитизации мощностью от нескольких сантиметров до десяти метров и более), если таковые присутствовали в обнажении. Особое внимание уделялось получению количественных характеристик трещинной сети (количество трещин на 1 м $^{2}$ изучаемой площадки $(N)$, среднее расстояние между трещинами соизмеримой длины для каждой из систем). Перечисленные данные использовались для составления предварительной схемы разломно-блокового строения участка локализации трубки Катока (рис. 6).

Для реконструкции полей тектонических напряжений и выделения основных этапов эволюции напряженного состояния района кимберлитовой трубка Катока нами использовались разрывы со смещениями маркеров (рис. 7, a), дайки (жилы) гранитов (см. рис. 4, б, в и $\partial$ ) и кимберлитов (рис. 7, 8), складки и будины (рис. 7, 2, д и e), а также трещины со штрихами скольжения (рис. 7, б и ж). Для всех перечисленных структур измерялись элементы залегания, для смещений маркеров дополнительно - тип и амплитуда подвижки, для складок шарнир и падение крыльев. Характеристика зеркал скольжения включала описание степени выраженности штрихов (неясные, ясные, ярко выраженные) и вторичных изменений на плоскостях трещин. Так, например, на них отмечалась эпидотизация, 


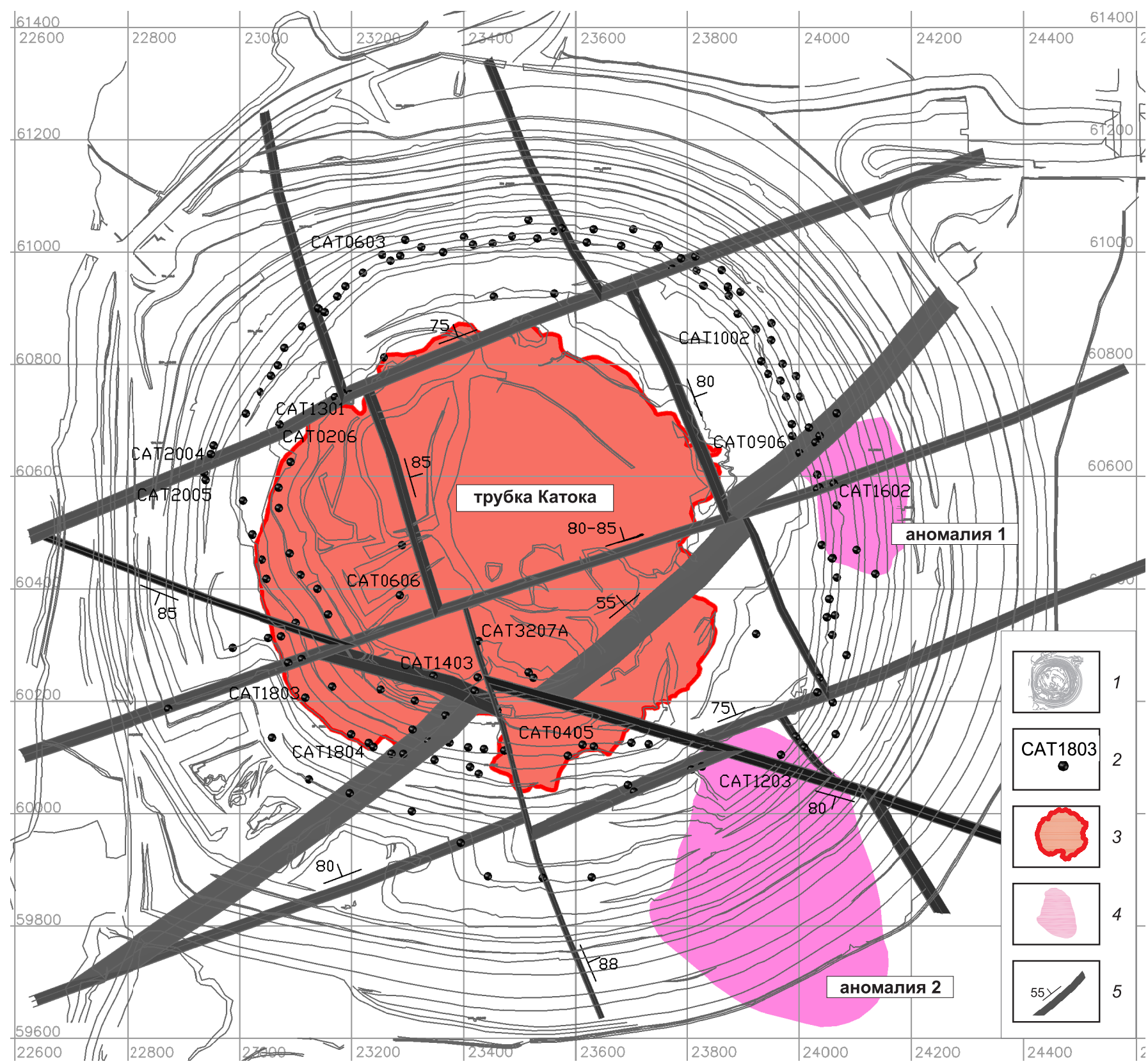

Рис. 6. Предварительная схема разломно-блокового строения участка локализации кимберлитовой трубки Катока и расположение точек геолого-структурных наблюдений в апреле 2017 г.

1 - положение горизонтов карьера на апрель 2017 г.; 2 - точки наблюдений (номера указаны только для точек, упоминаемых в тексте); 3 - контур трубки Катока; 4 - контуры непромышленных кимберлитовых тел (аномалий 1 и 3); 5 - разрывные нарушения и элементы их залегания.

Fig. 6. Preliminary schematic map showing the fault-block structure of the Catoca kimberlite pipe area and the points of geostructural observation conducted in April 2017.

1 - quarry horizons in April 2017; 2 - observation points (numbers are shown only for OPs mentioned in the text); 3 - contour of the Catoca pipe; 4 - contours of non-industrial kimberlite bodies (anomalies 1 and 3); 5 - faults (dip and strike).

которая свидетельствует о докайнозойском возрасте движений [Parfeevets, San'kov, 2006]. В других местах следы скольжения в гнейсах и кимберлитах фиксировались по корке кальцита, покрытых тонкой остекленевшей пленкой (рис. 7, ж), а также по глинке трения, что указывает на кайнозойский возраст смещений. Знак подвижки устанавливался по наличию маркеров и/или уступов-ступеней на поверхности тектонического зеркала, наличие которых предполагает, что вектор ориентирован в сторону беспрепятственного движения крыла разрыва. 


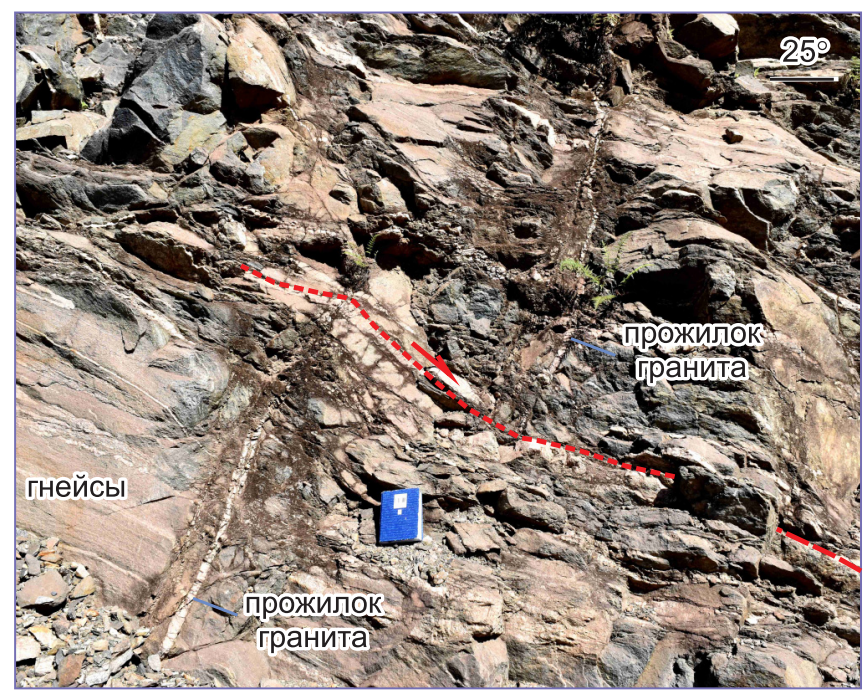

(a)
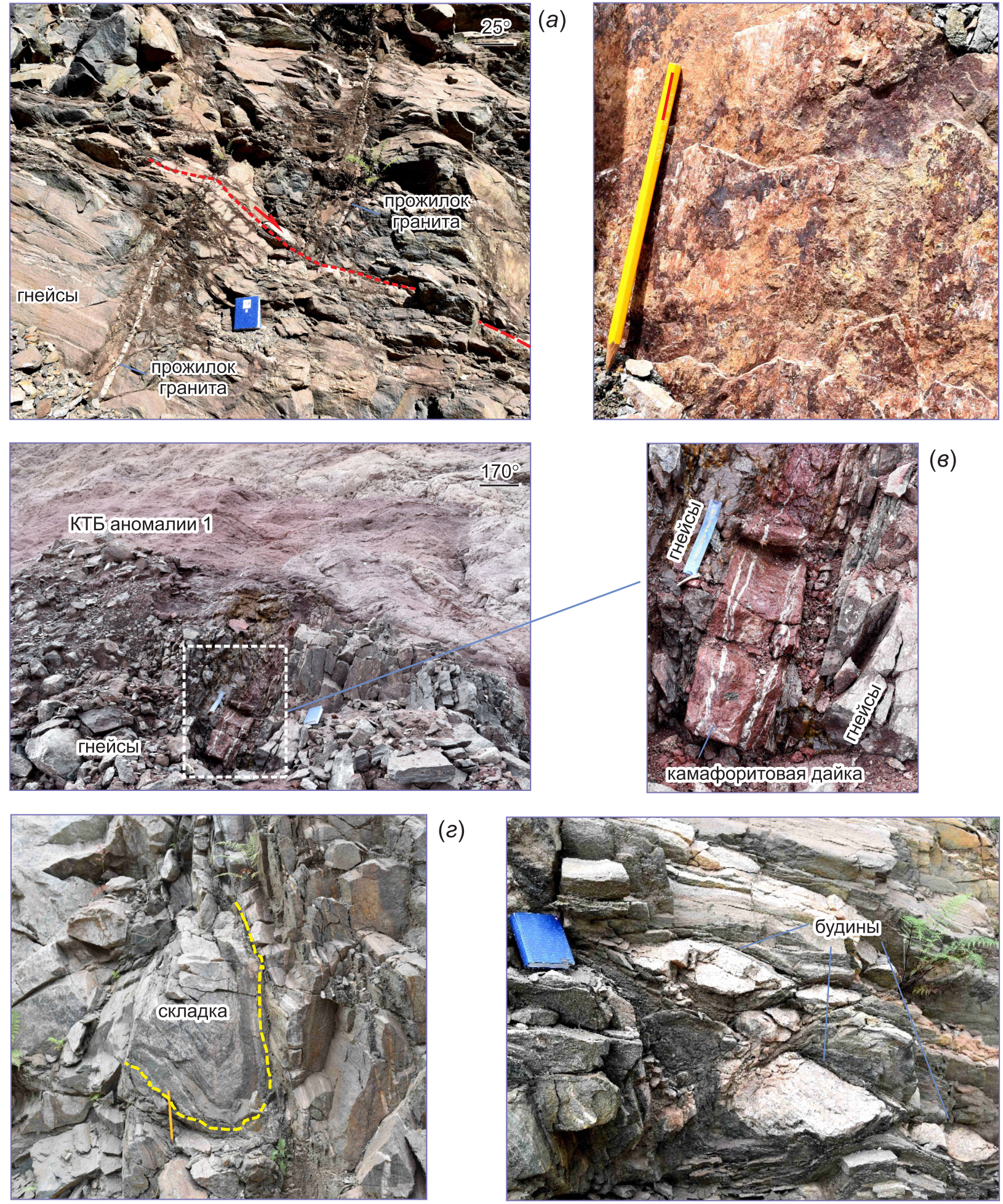

(d)
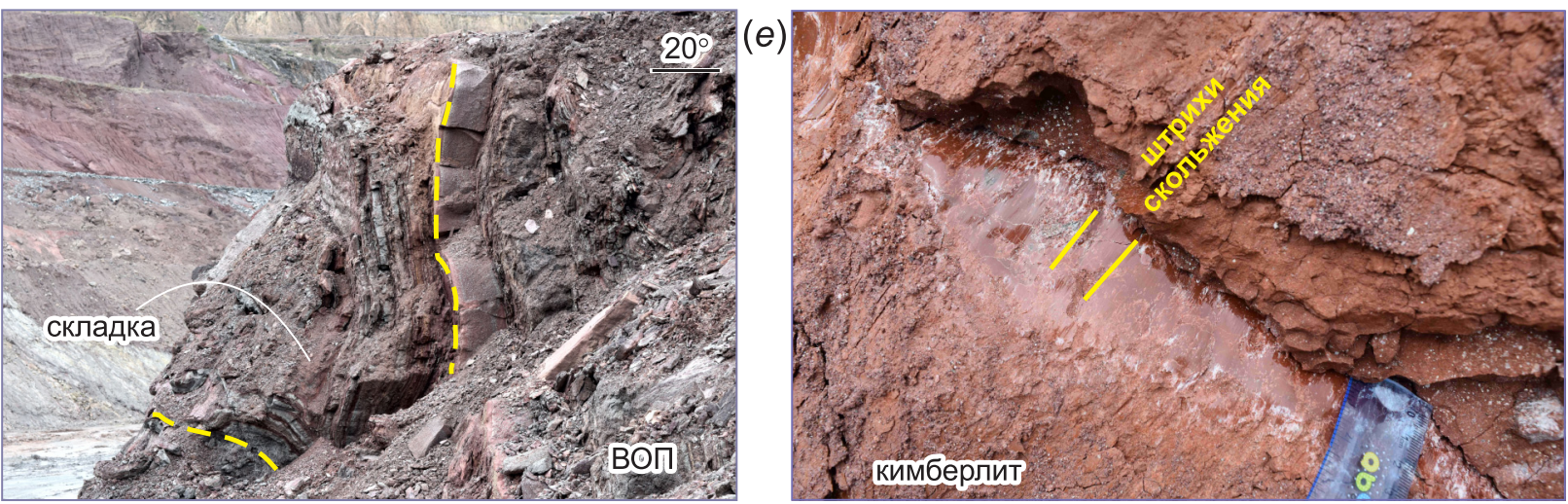
Рис. 7. Примеры линейно-ориентированных структур, использованных для реконструкций и выделения этапов эволюции напряженного состояния земной коры: (a) - сбросовая трещина с аз. пад. $310^{\circ} \angle 63^{\circ}$ со смещением прожилка гранита мощностью 2-3 см (сброс приурочен к дайке аплита мощностью до 10 см и древней зоне рассланцевания и трещиноватости мощностью 2-3 м с аз. пад. $315^{\circ} \angle 75^{\circ}$, за счет подновления зоны разрывов гнейсовидность становится положе), т.н. САТ2004; (б) - зеркало скольжения со взбросовыми штрихами по падению (красная стрелка указывает направление смещения) в зоне дробления и трещиноватости с аз. пад. 220-250 $\angle 50-55^{\circ}$ в гнейсах, т.н. САТ0603; (в) - дайка кимберлита с аз. пад. $342^{\circ} \angle 80^{\circ}$ и мощностью 0.2 м с конформными кальцитовыми прожилками (дайка срезана трещиной с аз. пад. $80^{\circ} \angle 20^{\circ}$ и перекрывается вишневыми кимберлитовыми туфобрекчиями, на которых лежат серо-зеленые массивные кимберлиты аномалии 1, сопутствующие основной трубке Катока), т.н. САТ1602; (2)-(d) - структуры сжатия в гнейсах, т.н. САТ2005; (e) - синклинальная складка в вулканогенноосадочных породах (ВОП), шарнир склоняется на $300^{\circ} \angle 6^{\circ}$, т.н. 3207а, вскрытая к ноябрю 2017 г. на горизонте 810 м; (ж) - штрихи скольжения в кимберлите.

Fig. 7. Examples of the linearly oriented structures used for the reconstructs and the identification of the stages in the evolution of the crustal stress state of the Catoca kimberlite pipe area: $(a)$ - normal fault, dip az. $310^{\circ} \angle 63^{\circ}$; offset $2-3 \mathrm{~cm}$ wide granite vein (this normal fault is associated with up to $10 \mathrm{~cm}$ wide aplite dike and the $2-3 \mathrm{~m}$ wide old zone of schistosity and fracturing, dip az. $315^{\circ} \angle 75^{\circ}$; due to the occurrence of new fractures, the gneissosity zone becomes flatter), 0P CAT2004; (б) - slickenside with reverse striations along the dip (the red arrow indicates the direction of displacement) in the zone of rock crushing and fracturing, dip az. $220-250^{\circ} \angle 50-55^{\circ}$, in gneiss, OP CAT0603; (8) - 0.2 wide kimberlite dike, dip az. $342^{\circ} \angle 80^{\circ}$, and conformal calcite veins (the dyke is cut off by the fracture, dip az. $80^{\circ} \angle 20^{\circ}$, and covered by the cherry-colour kimberlite tuff breccia overlaid by gray-green massive kimberlites of anomaly 1 , which accompany the main Catoca pipe), OP CAT 1602; $(2)-(\partial)$ - compression structures in gneiss, OP CAT 2005; $(e)$ - synclinal fold in volcanic-sedimentary rocks, the hinge tilts by $300^{\circ} \angle 6^{\circ}$, OP 3207 a (opened by November 2017 to the horizon of $810 \mathrm{~m}$ ); ( $)$ - striations in kimberlite.

Реконструкция полей напряжений проводилась с помощью программы «Win-Tensor» версии 5.8.6 [Delvaux, Sperner, 2003; Delvaux, 2012], которая находится в свободном доступе (http://www.damien delvaux.be/Tensor/WinTensor/win-tensor.html) и предлагает пользователю большие возможности управления интегрированной базой данных. В программе реализованы методы РВТ и правильных диэдров (right Dihedra), которые дают оценку предварительного стресс-тензора. Данное решение на следующем этапе улучшается процедурой оптимизации вращением, предложенной Д. Дельво [Delvaux, 1993]. Подробное описание методов изложено в ряде публикаций [Delvaux, Sperner, 2003; Parfeevets, San'kov, 2006; Delvaux, 2012; Kipata et al., 2013], но для дальнейшего изложения результатов исследований важно упомянуть некоторые детали.

Инверсионные (кинематические) методы базируются на принципе, заключающемся в том, что линия смещения параллельна направлению максимального касательного напряжения [Wallace, 1951; Gushchenko, 1979; Angelier, 1979]. Эти линии выражаются в виде штрихов и борозд скольжения, возникающих на трещинах под действием поля напряжений. Исходя из этих предпосылок, программа «WinTensor» позволяет рассчитывать четыре основных параметра стресс-тензора: положение осей главных нормальных напряжений - $\sigma_{1}$ (максимального сжимающего напряжения, далее ось сжатия), $\sigma_{2}$ (промежуточного сжимающего напряжения, далее промежуточная ось), $\sigma_{3}$ (минимального сжимающего на- пряжения, далее ось растяжения) и стресс-отношение $\mathrm{R}=\left(\sigma_{2}-\sigma_{3}\right) /\left(\sigma_{1}-\sigma_{3}\right)$ при $0 \leq \mathrm{R} \leq 1$, а также другие дополнительные характеристики [Delvaux, 2012]. Для определения режима напряжений (типа напряженного состояния земной коры) достаточно знать пространственное положение $\sigma_{1}, \sigma_{2}, \sigma_{3}$ и значение коэффициента формы эллипсоида напряжений $\mathrm{R}$. Выделяются радиальное растяжение $\left(\sigma_{1}\right.$ - вертикальна, $0<\mathrm{R}<0.25)$, чистое растяжение $\left(\sigma_{1}-\right.$ вертикальна, $0.25<\mathrm{R}<0.75)$, транстенсивный режим $\left(\sigma_{1}-\right.$ вертикальна, $0.75<\mathrm{R}<1$ - режим растяжение со сдвигом, или $\sigma_{2}$ - вертикальна, $1>\mathrm{R}>0.75$ - режим сдвига c растяжением), чистый сдвиг ( $\sigma_{2}-$ вертикальна, $0.75>\mathrm{R}<0.25)$, транспрессивный режим $\left(\sigma_{2}-\right.$ вертикальна, 0.25>R>0 - режим сдвига со сжатием, или $\sigma_{3}$ - вертикальна, $0<\mathrm{R}<0.25$ - режим сжатия со сдвигом), чистое сжатие ( $\sigma_{3}-$ вертикальна, $\left.0.25<\mathrm{R}<0.75\right)$, радиальное сжатие $\left(\sigma_{3}-\right.$ вертикальна, $\left.0.75<\mathrm{R}<1\right)$. 0 типе напряженного состояния также свидетельствует индекс R', который изменяется в пределах 0-1 для сбросового режима ( $\mathrm{R}^{\prime}=\mathrm{R}$ для субвертикальной оси $\left.\sigma_{1}\right), 1-2$ - для сдвигового $\left(R^{\prime}=2-R\right.$ для субвертикальной оси $\left.\sigma_{2}\right)$ и 2-3 для взбросового $\left(\mathrm{R}^{\prime}=2+\mathrm{R}\right.$ для субвертикальной оси $\sigma_{3}$ ). Качество полученного решения определяется буквами от А (лучшее) до Е (худшее) и зависит от количества данных в инверсии (n), отношения использованных данных к общему их числу (n/nt), среднего угла отклонения, наблюдаемого от теоретического направления смещения (AD), уровня достоверности знака смещения и типа данных (трещины со штрихами, отрывы, 
сколы без штрихов и т.д.). Перечисленные характеристики справедливы для определения параметров качества QRw и QRt, но последний также учитывает разнообразие ориентировок плоскостей и штрихов. Учитывая, что подход к анализу структур в программе «Win-Tensor» достаточно формализован, параметры стресс-тензора могут уточняться при получении их новых замеров.

Обработка линейно-ориентированных структурных элементов предусматривала анализ роза-диаграмм простирания разрывов с разными типами подвижек, даек и шарниров складок отдельно для вмещающих пород и кимберлитов, а также сопоставление этих данных между собой и с зонами разрывных нарушений. Затем все замеренные в карьере трещины со штрихами скольжения были сгруппированы в две основные выборки в зависимости от возраста пород (раннедокембрийские гнейсы и амфиболиты или раннемеловые кимберлитовые формации) и подверглись дальнейшему анализу. В итоге из каждой выборки трещин выделилось несколько однородных совокупностей и соответствующих им стресс-тензоров, характеризующих разновременные режимы напряжений, существовавшие в районе трубки Катока. Слияние трещин со штрихами со всех т.н. с замерами в первоначальные две выборки обусловлено их малым количеством, которое «окупается» разнообразием изученных структурных индикаторов на сравнительно небольшом по площади объекте. Для некоторых т.н. были получены индивидуальные решения, но в статье они приводятся только при необходимости.

\section{4. ВЫДЕЛЕНИЕ ОСНОВНЫХ ЭТАПОВ ЭВОЛЮЦИИ НАПРЯЖЕННОГО СОСТОЯНИЯ ЗЕМНОЙ КОРЫ И ОПРЕДЕЛЕНИЕ ПОРЯДКА ИХ ПРОЯВЛЕНИЯ ВО ВРЕМЕНИ}

В результате анализа линейно-ориентированных структурных элементов выделено шесть основных этапов эволюции напряженного состояния земной коры района кимберлитовой трубки Катока. Ниже они приводятся в порядке их проявления от древнего к более молодому возрасту.

\section{1. АНАЛИЗ ДАЕК ГРАНИТОВ И ВЫДЕЛЕНИЕ ПЕРВОГО ЭТАПА}

Наиболее древними из изученных нами структур являются дайки гранитов и горнблендитов предположительно архейского возраста, которые, судя по их взаимоотношению с вмещающими породами (см. рис. $4,6-\partial$ ) и замерам элементов залегания (рис. $8, a$ ), внедрялись в несколько этапов мигматизации. Всего на изученных горизонтах карьера было замерено 36 даек кислого состава. Их преобладающее направление - северо-восточное (рис. 8, б) - в первом приближении отвечает северо-западному простиранию оси растяжения в момент формирования структур. В то же время разнообразие углов падения даек (рис. 8, в) свидетельствует как минимум о двух крупных геодинамических событиях с образованием более ранних крутопадающих и более поздних пологопадающих тел. Следуя этим наблюдениям, мы создали две выборки, первая из которых включала 17 даек северовосточной ориентировки, падающих под углами $50-85^{\circ}$ (рис. $8,2, \partial$ ), вторая - 15 даек с углами падения $0-49^{\circ}$ вне зависимости от их простирания (рис. 9 , б). Четыре замера не удовлетворяли критериям группирования. Дайки первой выборки, за исключением одной в т.н. САТ1806, где гнейсовидность локально разворачивается на $5^{\circ} \angle 63^{\circ}$, конформны залеганию пород. В ходе их анализа с помощью программы «Win-Tensor» реконструировано поле напряжений с северо-западным положением оси $\sigma_{3}=142^{\circ} \angle 7^{\circ}$. Коэффициенты $\mathrm{R}=0.8$ и $\mathrm{R}^{\prime}=1$ указывают на режим транстенсии (см. рис. 8,2 ). В решении отмечается высокая величина функции минимизации F5, что свидетельствует о большом разбросе элементов залегания интрузий относительно полученного стресс-тензора. Тем не менее мы не стали разделять наклонные и крутопадающие дайки, простирающиеся в сравнительно широком диапазоне на $300-345^{\circ}$, полагая, что они могли сформироваться в течение одного продолжительного этапа развития земной коры в режиме растяжения со сдвигом, в ходе которого возможны локальные вариации поля напряжений или который может быть разделен на подэтапы (чистого растяжения, транстенсии, сдвига) в случае большего количества измерений. Качество полученного решения $\mathrm{QRw}$ и $\mathrm{QRw}$ оценивается как среднее (см. рис. 8, 2).

\section{2. ВТОРОЙ эТАП}

За господствующим транстенсионным геодинамическим режимом последовал этап северо-западного сжатия в усредненном направлении $310^{\circ}$ (рис. 9). Этот этап, выделяющийся по анализу штрихов скольжения (рис. 9, $a$ ), проявляется только во вмещающих горных породах и подтверждается наличием взбросовых смещений маркеров по восток-северо-восточным разрывам (рис. 9, б, и рис. 10). Максимальные амплитуды подвижек 1.35 и 1.5 м по трещинам с аз. пад. $150^{\circ} \angle 60-75^{\circ}$ и $335^{\circ} \angle 70^{\circ}$ в гнейсах зарегистрированы в т.н. САТ1002 и CAT1804, где смещаются дайки гранитов с аз. пад. $345^{\circ} \angle 65^{\circ}$ (рис. $10, a$ ) и $300^{\circ} \angle 55^{\circ}$ (рис. 10, б), соответственно. Некоторые из взбросов подобной геометрии секут зоны течения и древнее рассланцевание пород. В пользу существования этапа северо-запад- 

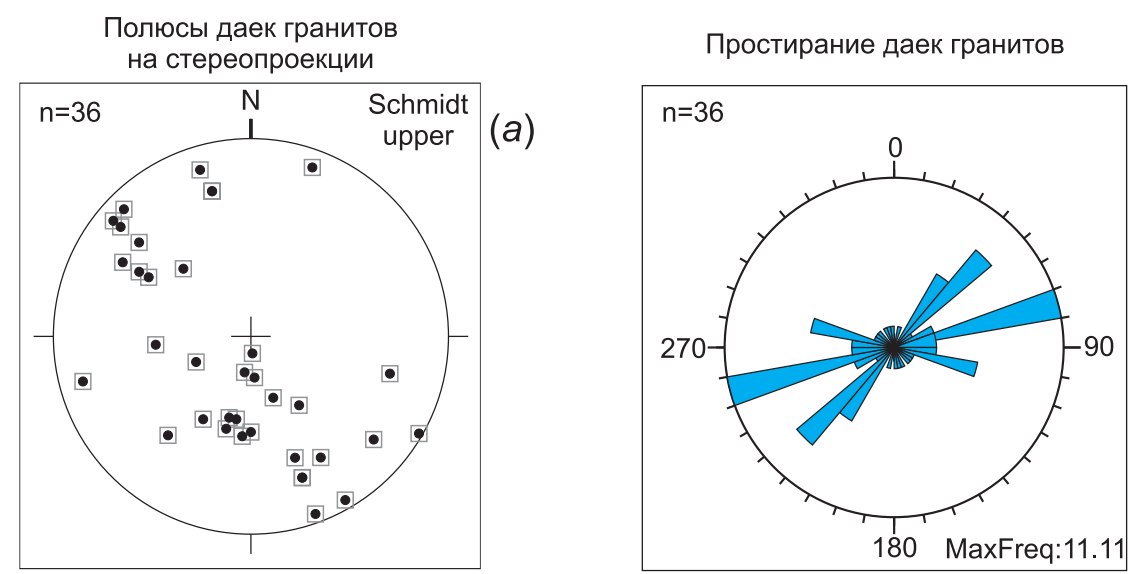

(б)
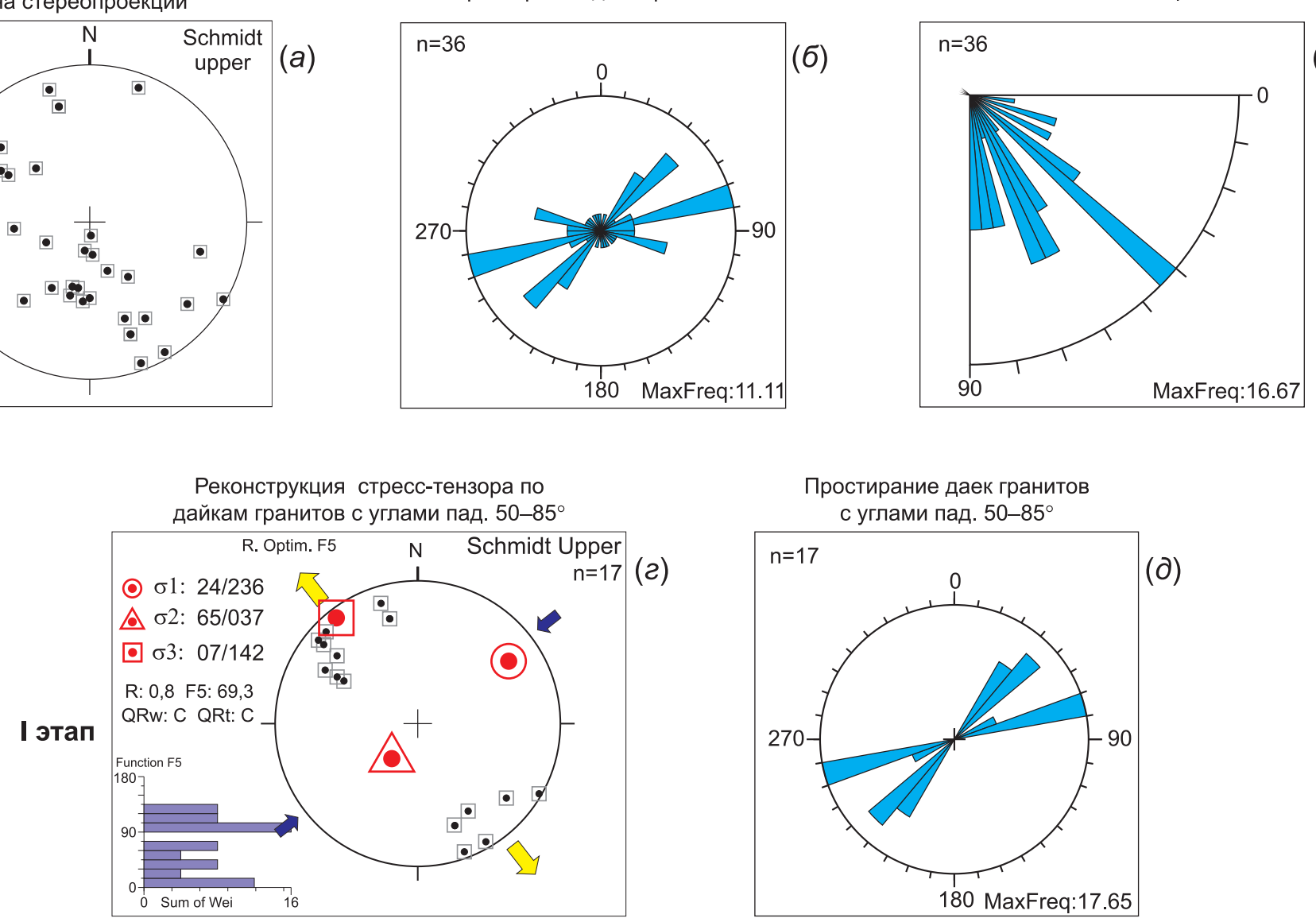

Рис. 8. Предварительный анализ даек гранитов $(a-8)$ и выделение I этапа транстенсии $(2-\partial)$. N - количество замеров.

Fig. 8. Preliminary analysis of granites dikes $(a-8)$. Identification of stage 1 (transtension) $(2-\partial)$. N - number of measurements.

ного сжатия свидетельствуют также пологие и наклонные дайки (вторая выборка), реконструкция напряженного состояния по которым показывает режим всестороннего субгоризонтального сжатия в направлениях $208^{\circ} \angle 28^{\circ}\left(\sigma_{1}\right)$ и $117^{\circ} \angle 2^{\circ}\left(\sigma_{2}\right)$ (см. рис. 9, в). В этом поле напряжений могли также сформироваться складки и будины, шарниры и длинные оси которых соответственно простираются на $30-60^{\circ}$. Это предполагает, что ось сжатия на время их образования склонялась на $300-330^{\circ}$ (см. рис. 9, 2). Несмотря на то, что параметры качества QRw и QRw ниже среднего у стресс-тензоров либо равны ему (см. рис. 9, $a$ и в), существование данного этапа по совокупности данных не вызывает сомнений.

Если говорить о возрасте и источнике северозападного сжатия, то его можно предположительно ассоциировать с континентальной коллизией между кратонами Конго и Калахари, завершившейся 530 млн лет назад [John et al., 2004]. В результате образовались Дамарский, Луфилианский и Замбий- ский орогенные пояса, составляющие единую систему генерализованного северо-восточного простирания (см. рис. 1). Это событие пришлось на последнюю стадию косой коллизии между Восточной и Западной Гондваной, начавшейся около 650 млн лет назад в неопротерозое с северо-востока Африканского континента и сформировавшей к периоду 525-510 млн лет с его восточной стороны горную цепь длиной более 8000 км и шириной более 1000 км [Squire et al., 2006].

\section{3. ТРЕТИЙ ЭТАП}

Третий этап эволюции напряженного состояния земной коры наиболее четко проявлен в гнейсах по штрихам скольжения. Согласно коэффициенту $\mathrm{R}=0.23$, режим деформирования определяется как радиальное растяжение, но близкое к чистому растяжению (R=0.25-0.75) в направлении $331^{\circ}$ (рис. $11, a)$. В пользу существования данного этапа как самостоятельного, отличного от первого, свиде- 


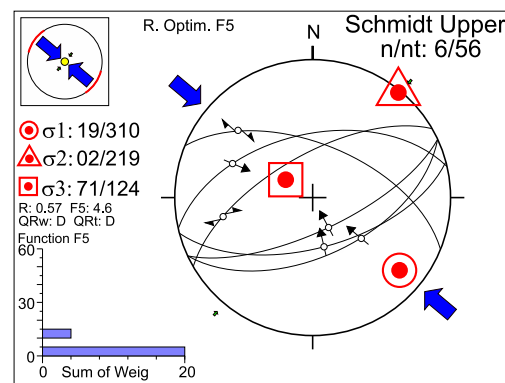

ІІ этап

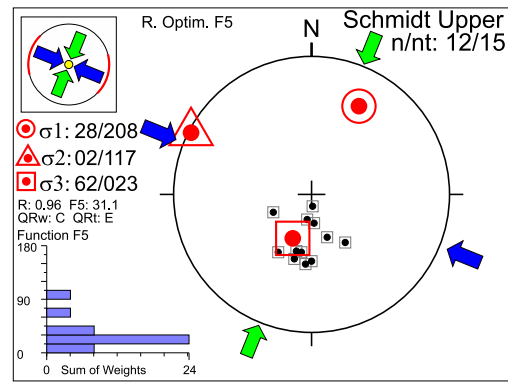

(a)

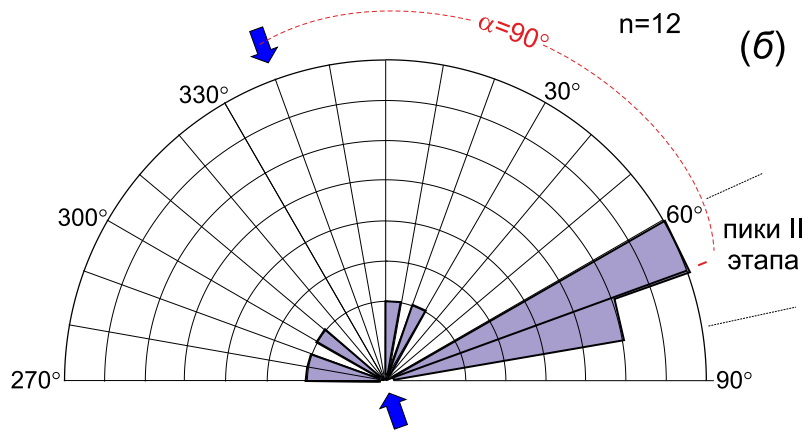

$(8)$

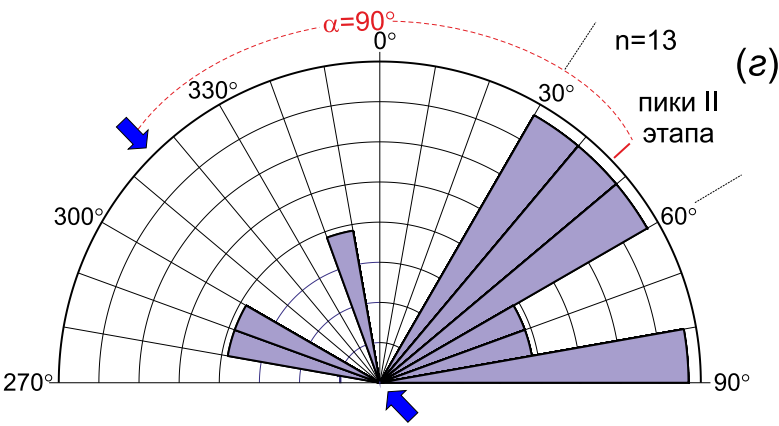

(2)

Рис. 9. Геолого-структурные доказательства II этапа северо-восточного сжатия: $(a)$ - реконструкция стресс-тензора по штрихам скольжения в гнейсах (4-е по значимости решение по совокупности данных); (б) - простирание взбросов в гнейсах; ( 8 ) - реконструкция стресс-тензора по дайкам гранитов с углами пад. $0-49^{\circ}$; (2) - простирание шарниров складок и длинных осей будин в гнейсах.

Fig. 9. Geostructural evidence of stage 2 (NE compression) in the evolution of the crustal stress state of the Catoca kimberlite pipe area: $(a)$ - stress tensor reconstructed from striations in gneiss (the $4^{\text {th }}$ most significant solution from the database); (б) - strike of faults in gneisses; ( $(8)$ - stress tensor reconstructed for granite dikes, dip az. $0-49^{\circ}$; (2) - strike of fold hinges and long axes of boudins in gneiss.

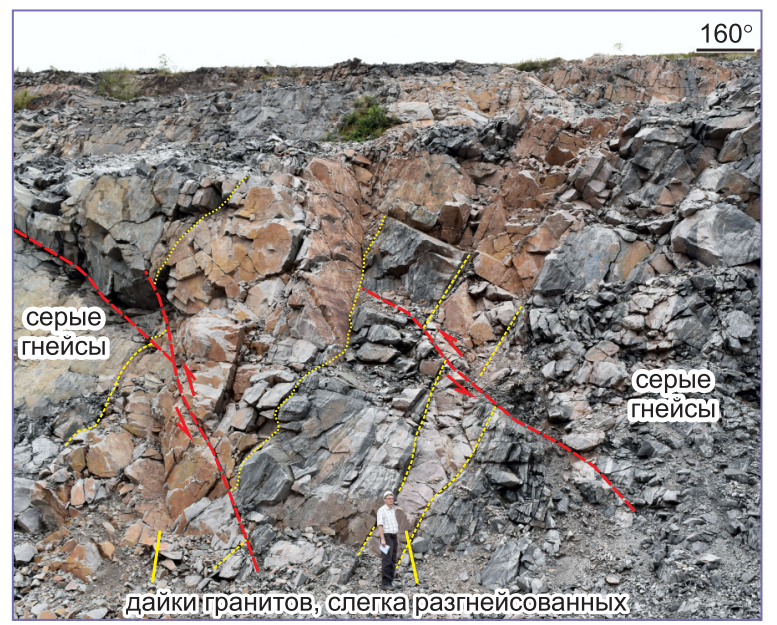

(a)

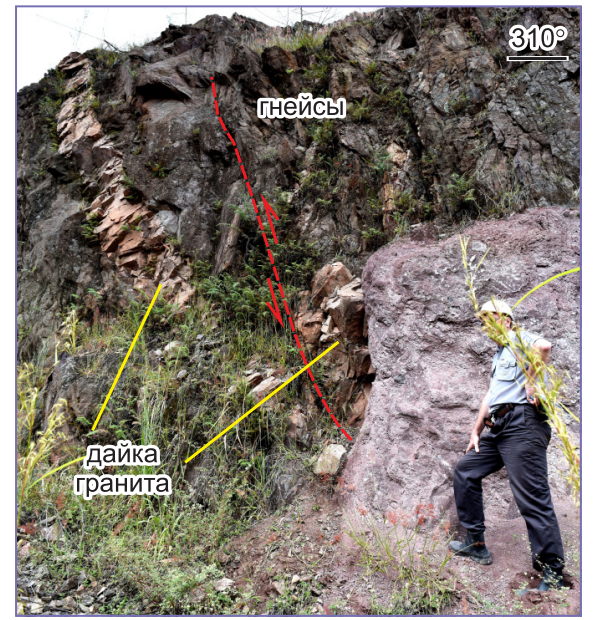

Рис. 10. Взбросовые смещения даек розовых среднезернистых гранитов в серых гнейсах, отвечающие II этапу эволюции напряженного состояния земной коры района кимберлитовой трубки Катока: $(a)$ - дайки гранитов с аз. пад. $345^{\circ} \angle 65^{\circ}$ (согласные гнейсовидности), смещенные по зонам дробления мощностью 0.1-0.5 м с аз. пад. $150^{\circ} \angle 60-75^{\circ}$, амплитуда - 1.35 м, т.н. САТ1002; (б) - дайка среднезернистого гранита с аз. пад. $300^{\circ} \angle 55^{\circ}$ в гнейсах, смещенная по взбросу с аз. пад. $335^{\circ} \angle 70^{\circ}$, амплитуда 1.5 м (штрихи скольжения по падению), т.н. САТ1804.

Fig. 10. Reverse shearing of the dikes of pink medium-grained granite in gray gneiss, which correspond to stage 2 in the evolution of the crustal stress state of the Catoca kimberlite pipe area: $(a)$ - granite dikes, dip az. $345^{\circ} \angle 65^{\circ}$ (concordant with gneissosity) displaced along 0.1-0.5 m wide rock-crush zones, dip az. $150^{\circ} \angle 60-75^{\circ}, 1.35 \mathrm{~m}$ amplitude, OP CAT1002; (б) - medium-grained granite dike, dip az. $300^{\circ} \angle 55^{\circ}$ in gneiss, displaced along the reverse fault, dip az. $335^{\circ} \angle 70^{\circ}, 1.5 \mathrm{~m}$ amplitude (striations along the dip), OP CAT1804. 


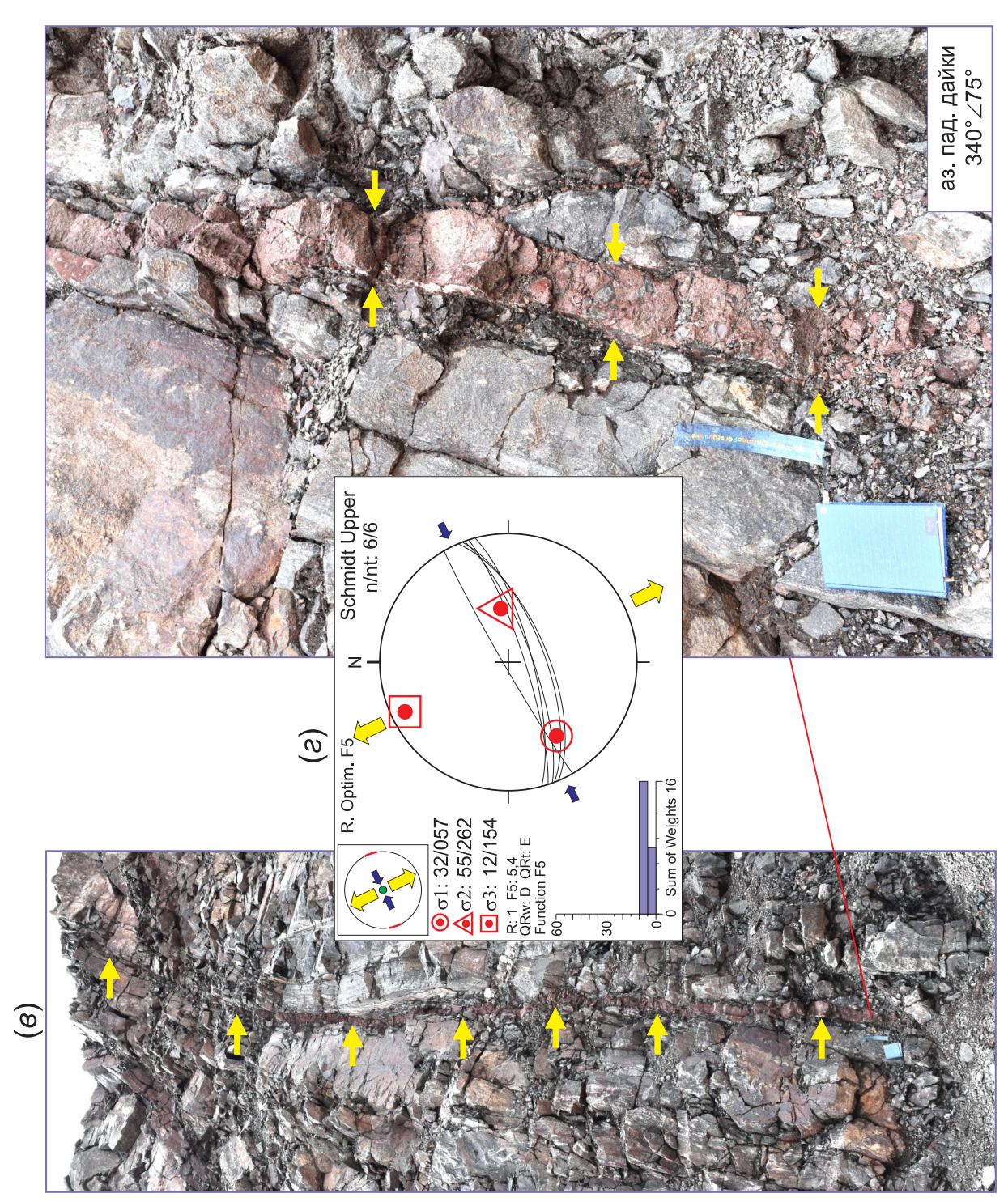

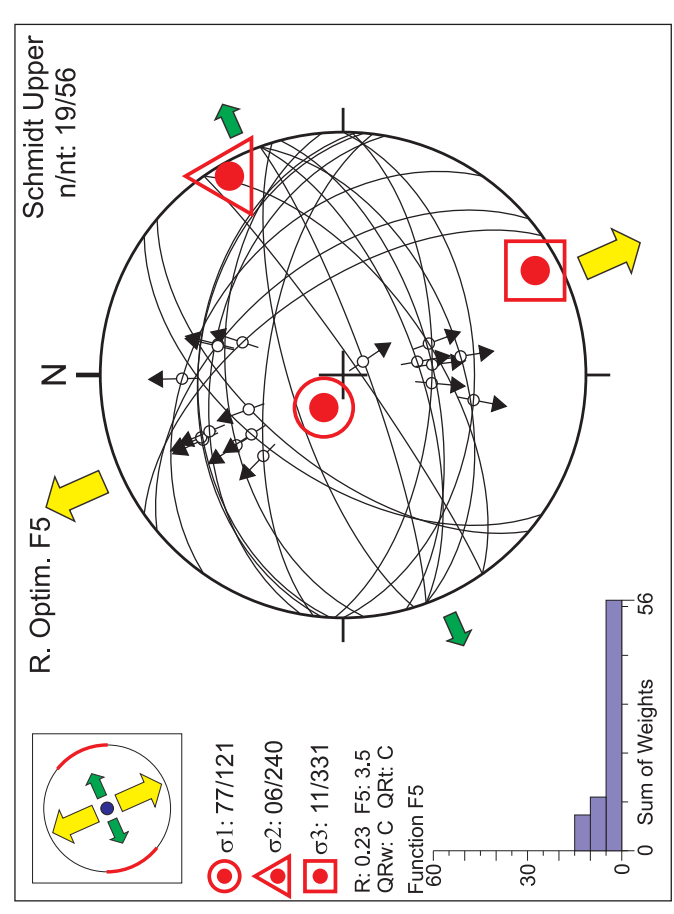

త్

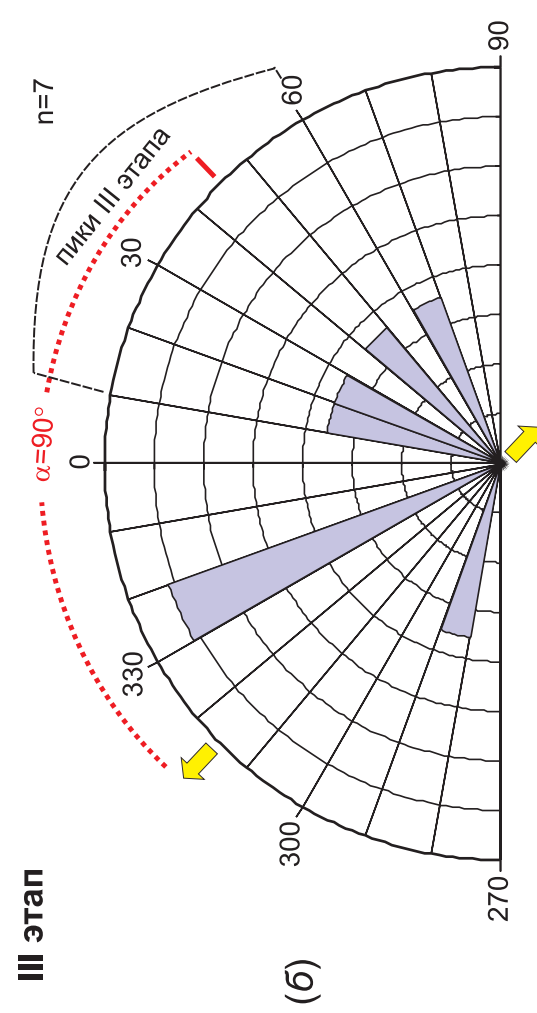

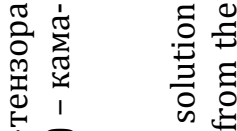

记

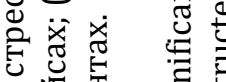

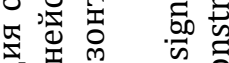

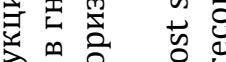

क

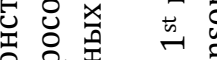

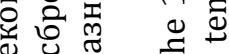

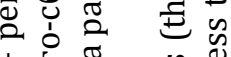

1 焉娄

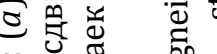

薄零

풘

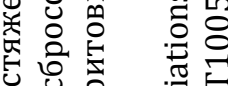

更

2 क क

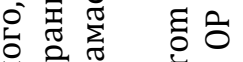

웜워

预氜 可

즁을

원

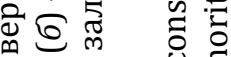

Uัँ

음

要

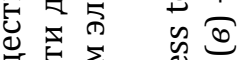

至施包

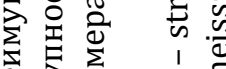

हे

F $\Xi$

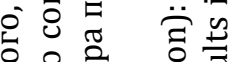

웅유 융

요

త్

政

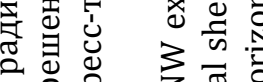

해

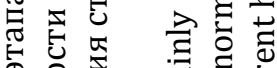

更完

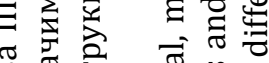

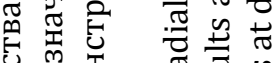

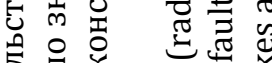

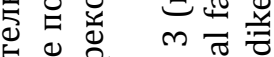

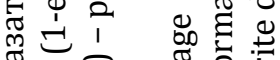

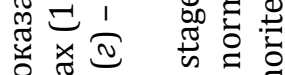

论

可 :

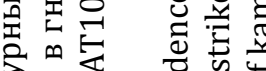

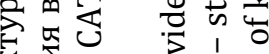

可产焉

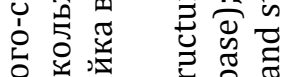

농

\& $\sum_{0}$

.

تే

当荅

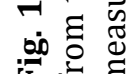


тельствует сбросовая подвижка 0.7 м по трещине, приуроченной к дайке аплита, с аз. пад. $310^{\circ} \angle 63^{\circ}$ в т.н. САТ2004 (см. рис. 7, a). Смещается прожилок гранита мощностью 2-3 см, рассекающий поперек и гнейсовидность, и дайку. Смещения совпадают с активизированной зоной рассланцевания и трещиноватости с аз. пад. $315^{\circ} \angle 75^{\circ}$, мощностью 2-3 м, наблюдавшейся в торцовой части того же выхода. Всего из семи сбросовых и сдвиго-сбросовых смещений маркеров четыре удовлетворяют геодинамическому режиму третьего выделенного этапа (рис. 11, б, северо-восточные пики на роза-диаграмме).

Наиболее вероятно то, что возникновение рассматриваемого поля напряжений привело к активизации региональных разломов «коридора Лукапа» (см. рис. 2), который, согласно работе [Zinchen$k o, 2015]$, в верхнем палеозое развивался в условиях растяжения земной коры как внутриплатформенный авлакоген, имевший морфологию грабена. Возможно, в конце именно этого этапа произошло внедрение кимберлитовой магмы, которому предшествовало образование восток-северо-восточных камафоритовых даек (определение камафорита сделано Е.В. Скляровым) мощностью первые десятки сантиметров (см. рис. 7, в; 11, в). Простирание этих даек предполагает растяжение в северо-западном направлении, а режим деформирования транстенсионный (рис. 11, 2). Очевидно, это были первые интрузии раннемелового возраста по аналогии с указанным в работах [Robles-Cruz et al., 2010; Zinchenko, 2015] возрастом трубки Катока, за которыми последовало становление основного кимберлитового тела. В т.н. САТ1602 камафоритовая дайка с аз. пад. $342^{\circ} \angle 80^{\circ}$ мощностью 0.2 м срезана трещиной $80^{\circ} \angle 20^{\circ}$ и перекрыта КТБ и КБМ аномалии (сопутствующее трубке Катока кимберлитовое тело, см. рис. 7, в). После интрудирования земной коры почти сразу, по-видимому, произошла смена ее напряженного состояния, в результате чего «следов» существования данного поля растяжения в кимберлитах трубки Катока не наблюдается, хотя, возможно, они еще не были обнаружены.

Отнесение третьего этапа ко времени кимберлитового магматизма хорошо согласуется с выводами С. Уайта и его соавторов [White et al., 1995], которые, проанализировав структурное положение кимберлитовых и лампроитовых тел, пришли к заключению, что тектоническая активность в режимах растяжения и сдвига, обычно следующая за периодом главной стадии развития океанического или континентального рифтинга, благоприятна для внедрения трубок. Кроме того, С. Уайт пришел к заключению, что кимберлитовые провинции ассоциируются с коровыми структурами более низкого ранга в пределах коридоров и зон на древних платформах, которые расположены ортогонально или косо к главному направлению линейных грабенов, а главные кимберлитовые поля в СевероВосточной Анголе (провинция I и часть провинции IV) расположены в областях, в которых востоксеверо-восточные второстепенные разрывы доминируют (см. рис. 2, б). Действительно, результаты нашего картирования показывают доминирование разрывных нарушений восток-северо-восточного направления на участке локализации трубки Катока (см. рис. 6; рис. 12).

\section{4. ЧЕТВЕРТЫЙ ЭТАП}

Четвертый этап развития земной коры района кимберлитовой трубки Катока характеризуется северо-западным растяжением и северо-восточным сжатием. Режим деформирования определяется как сдвиговый. Данный этап реконструируется в гнейсах по штрихам скольжения со средним по качеству решением и хорошим коэффициентом функции оптимизации (рис. 13, a), а также в т.н. CAT1403, где породы представлены кимберлитами. В последних решение нельзя отнести к надежным из-за соответствующих параметров (рис. 13, б), но оно дает основание определить время существования сдвигового этапа после предшествующего растяжения земной коры. В течение господства сдвигового режима в докембрийском фундаменте ведущими были разрывы восток-северо-восточного направления, расположенные в пределах «коридора Лукапа». При этом в активизацию также активно вовлекались тектонические нарушения субширотного, северо-восточного и северо-западного простирания.

Четвертый этап, по-видимому, можно отнести к переходному от рудного к пострудному времени кимберлитового магматизма, но для окончательного вывода необходимы более детальные структурно-геологические и тектонофизические исследования.

\section{5. ПЯтЫЙ эТАП}

Данный этап сжатия в северо-восточном направлении уверенно идентифицируется в кимберлитах и породах комплекса ВОП раннемелового возраста. По трещинам со штрихами скольжения в кимберлитах реконструируется 2-е по значимости решение (рис. 14, a). Усредненное склонение оси сжатия $\sigma_{1}-33^{\circ} \angle 16^{\circ}$, но местами отмечается значительный разворот на восток, что связано, очевидно, с локальными вариациями поля напряжений (рис. 14, б). В гнейсах, в т.н. САТ0603, северо-восточное сжатие также фиксируется, но решение незначимое из-за малого количества трещин со штрихами и 

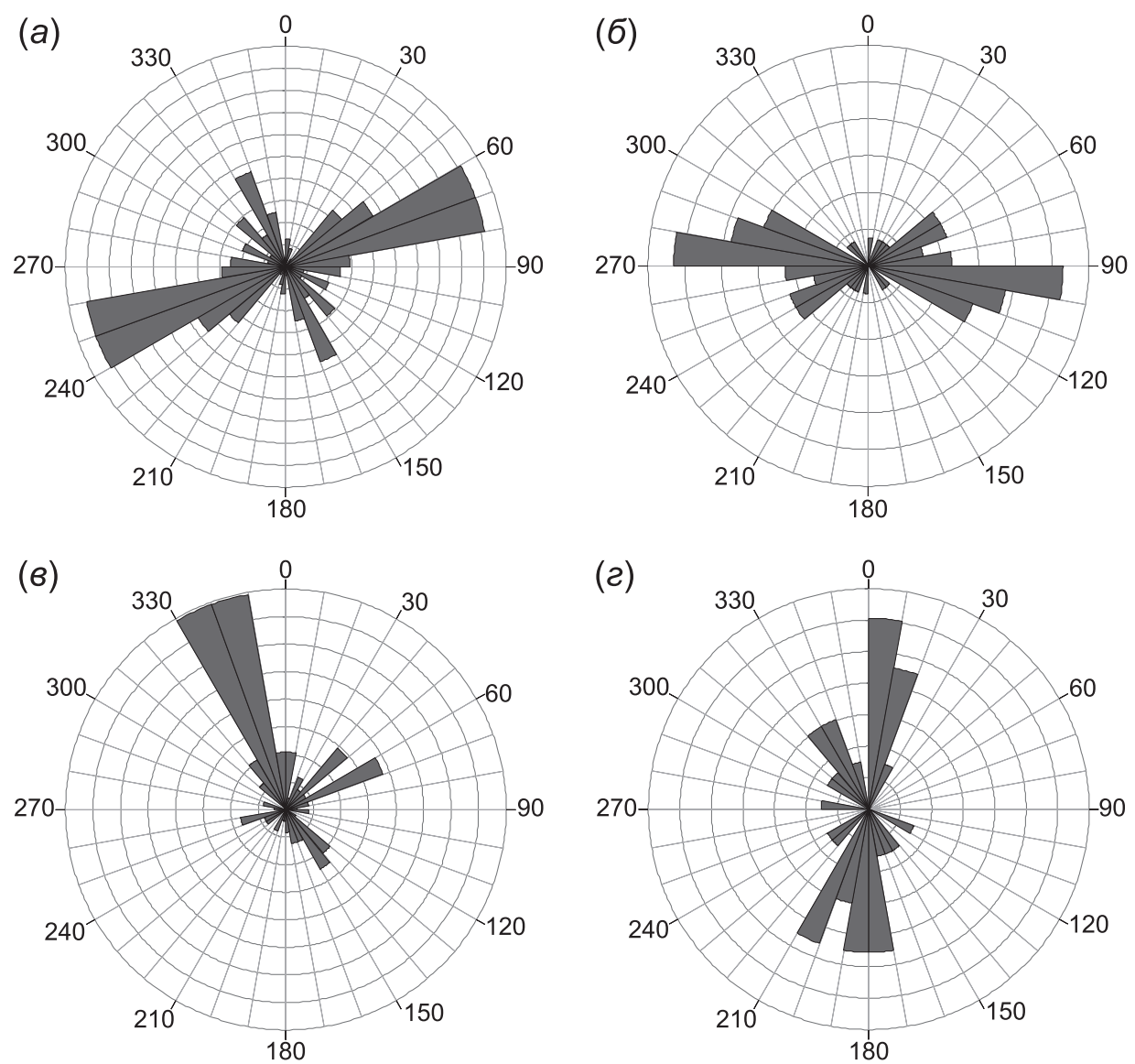

Рис. 12. Роза-диаграммы простираний и падений зон разрывных нарушений в карьере трубки Катока: (a), (б) диаграммы простираний субвертикальных (a) и наклонных (б) разрывных нарушений; (в), (2) - диаграммы падений субвертикальных (в) и наклонных (2) нарушений.

Fig. 12. Rose diagrams for the Catoca pipe quarry: strike of subvertical (a) and inclined (б) faults, and dip of subvertical ( 8 ) and inclined (2) faults.
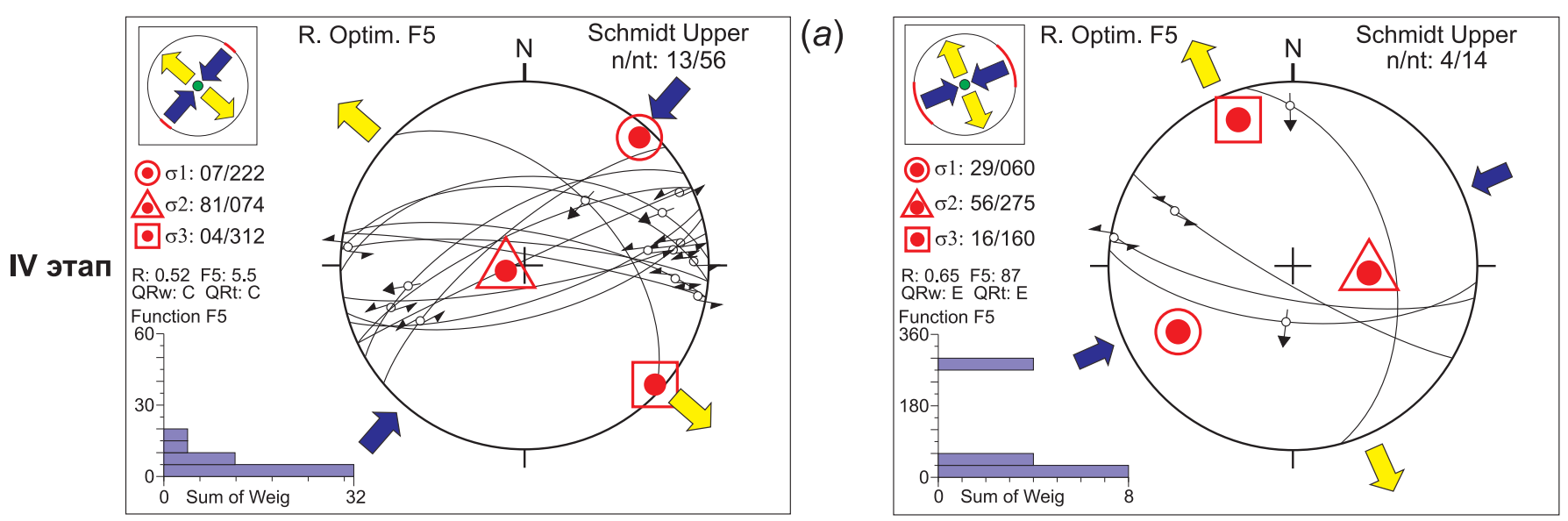

(6)

Рис. 13. Геолого-структурные доказательства IV сдвигового этапа, характеризующегося северо-западным растяжением и северо-восточным сжатием: $(a)$ - реконструкция стресс-тензора по штрихам скольжения в гнейсах (2-е по значимости решение по совокупности данных); (б) - реконструкция 2-го стресс-тензора по штрихам скольжения в кимберлитах раннего мела для т.н. САТ1403 (ненадежное решение).

Fig. 13. Geostructural evidence of stage 4 (shearing, NW extension, and NE compression): (a) - stress tensor reconstructed from striations in gneiss (the $2^{\text {nd }}$ most significant solution from the database); (б) - the $2^{\text {nd }}$ stress tensor reconstructed from striations in the Early Cretaceous kimberlite at OP CAT1403 (unreliable solution). 


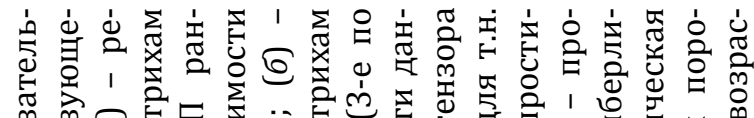

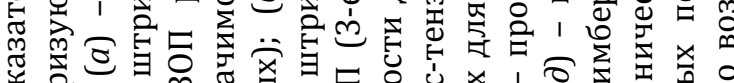

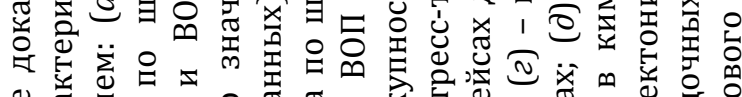

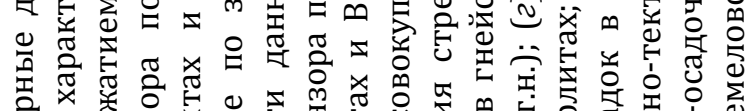

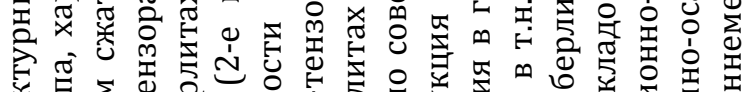

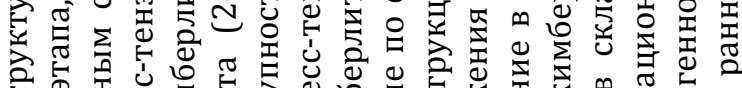

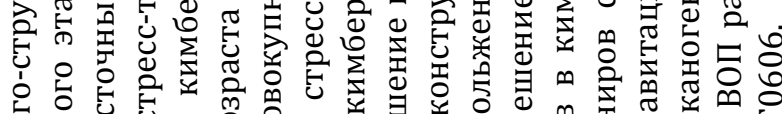

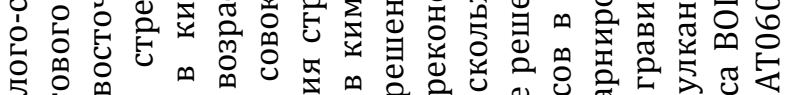

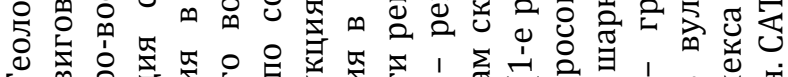

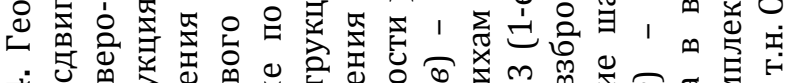
犬广

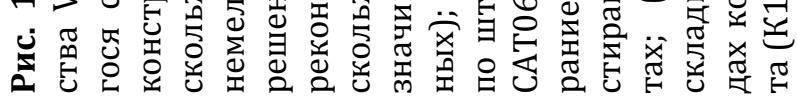

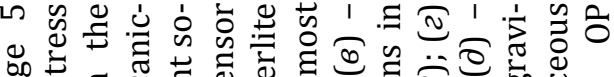

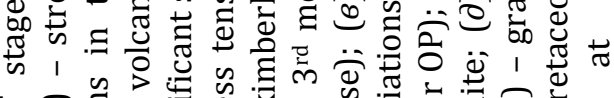

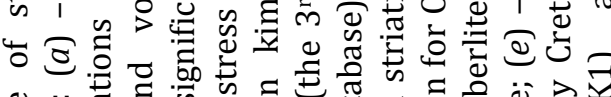

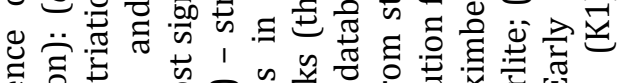

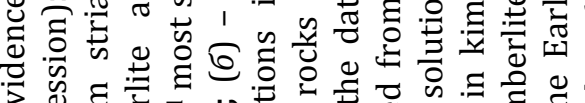

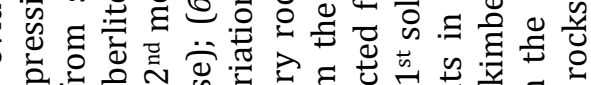

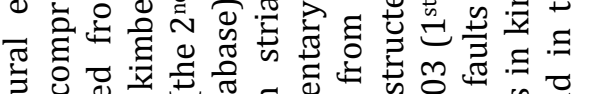

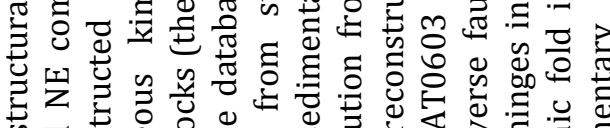

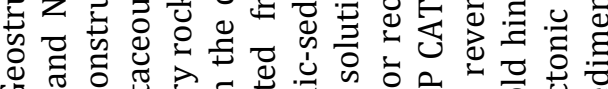

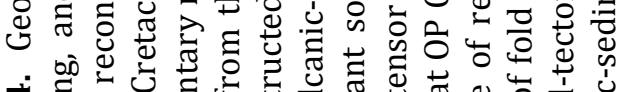

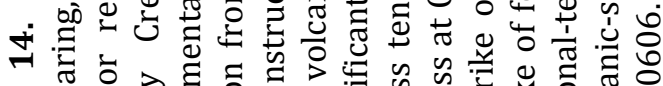

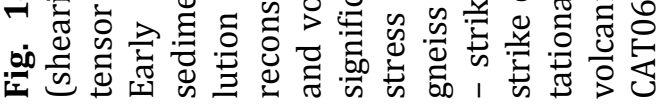

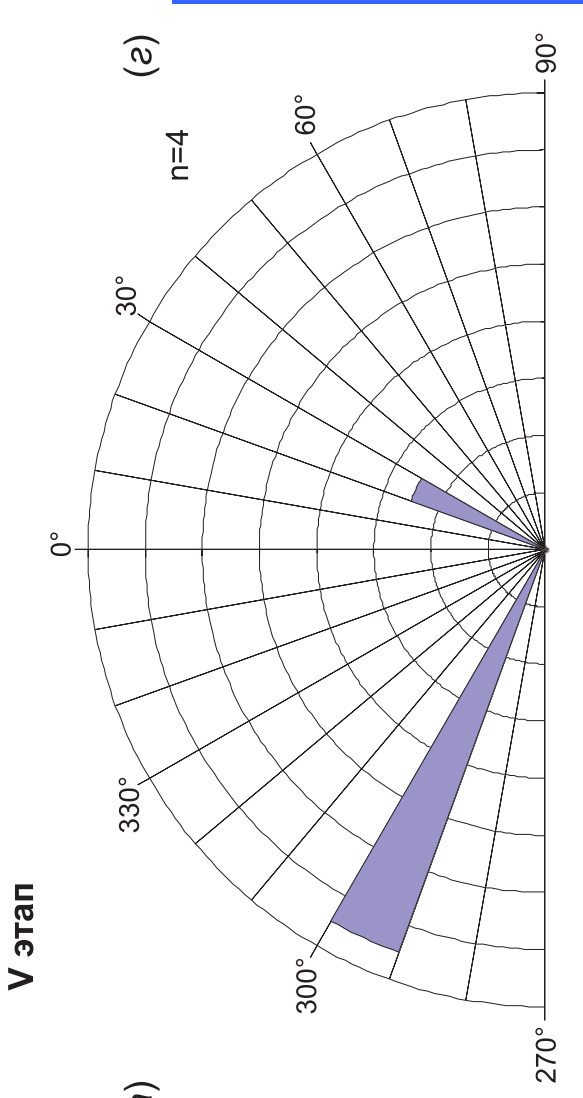

త్

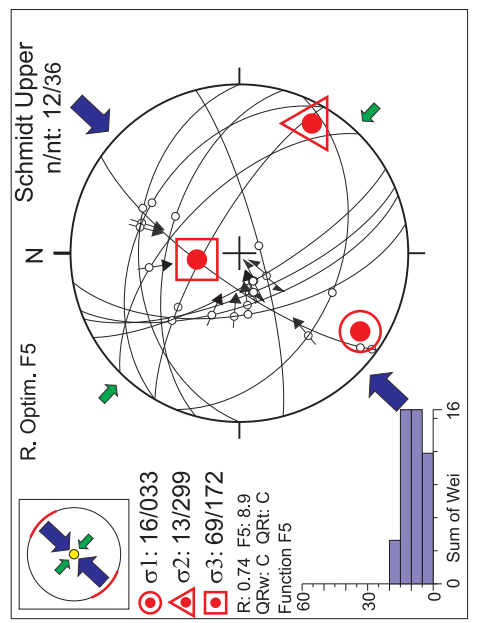

o

$\therefore$

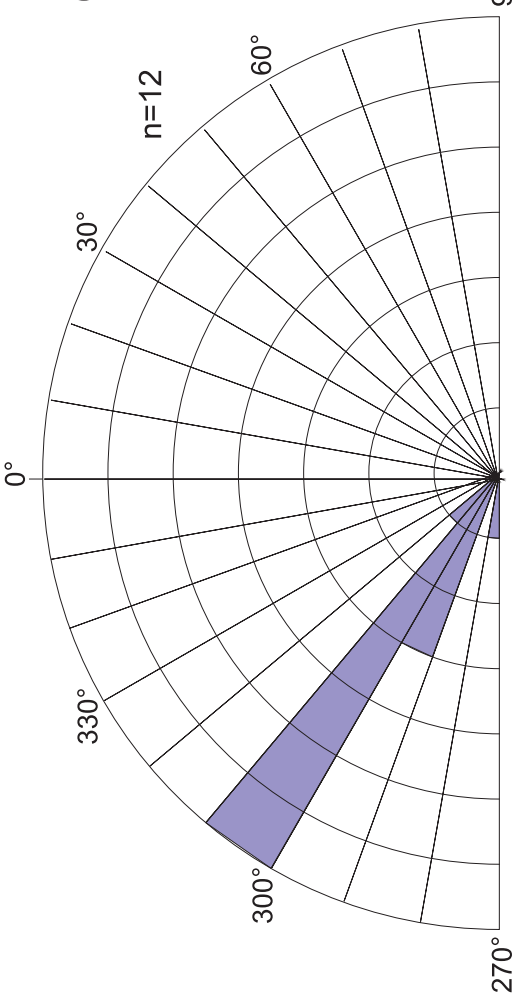

e

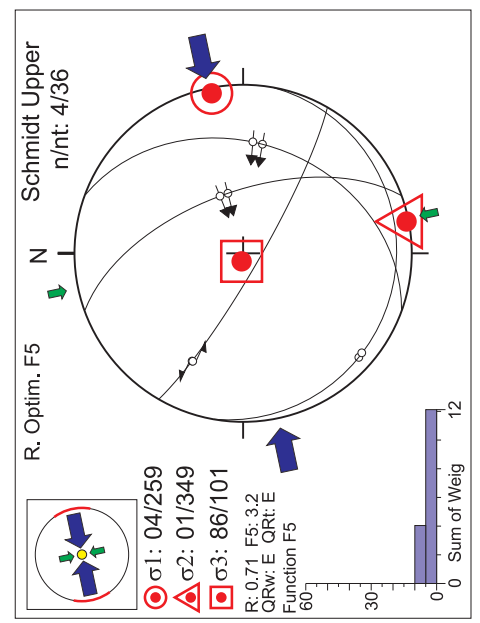

(])

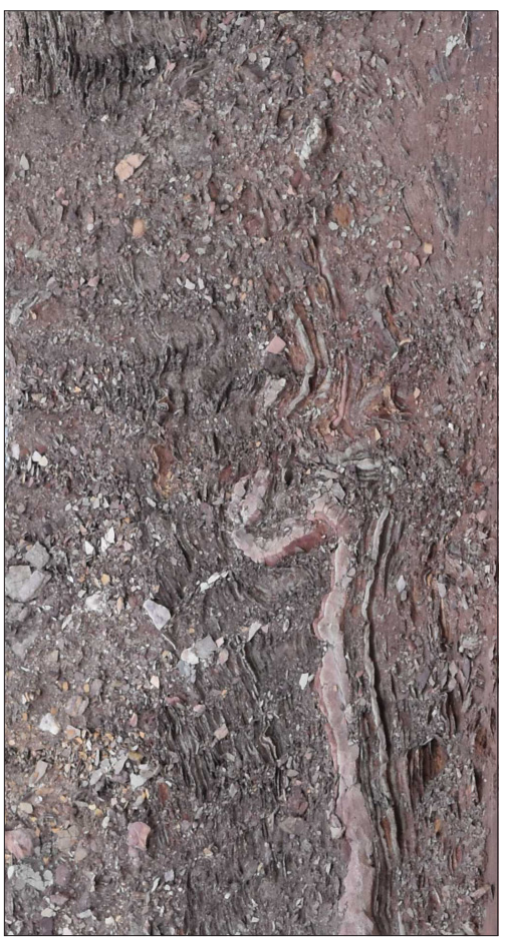

क्

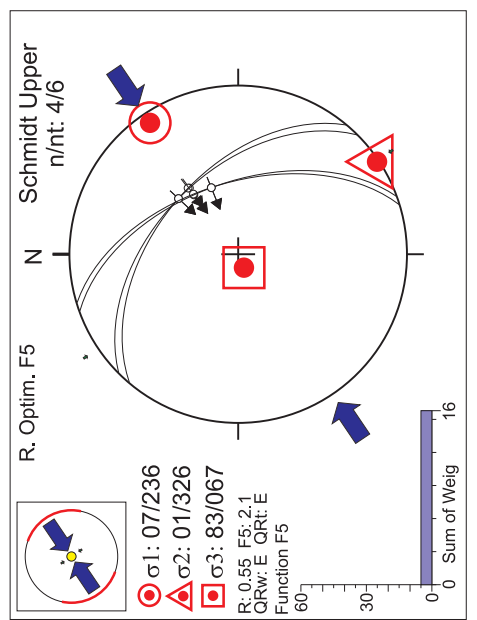



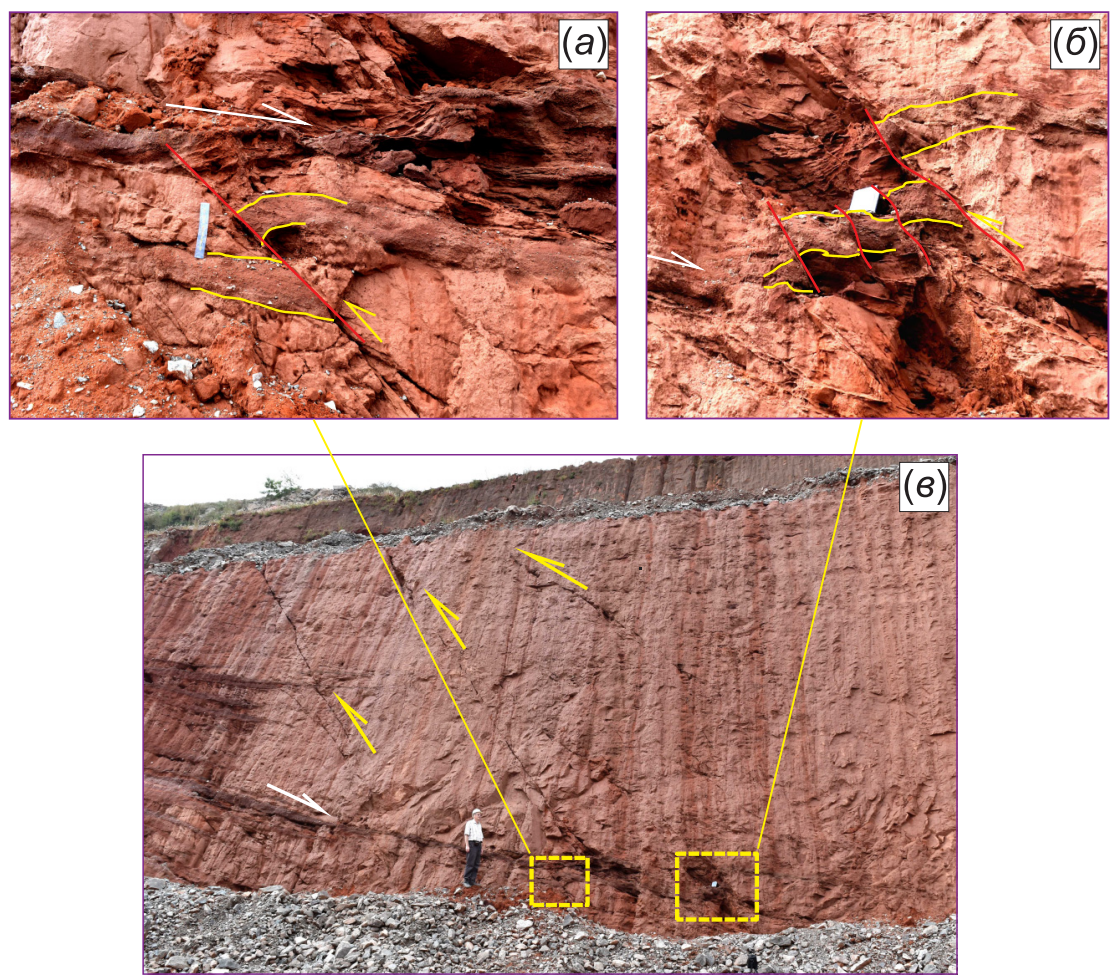

Рис. 15. Взбросовые и сбросовые смещения бардовых туфов в туфопесчаниках кирпичного цвета раннемелового возраста (породы сопутствующей кимберлитовой «аномалии»), отвечающие соответственно V и VI этапам эволюции напряженного состояния земной коры района кимберлитовой трубки Катока, т.н. CAT1203: (a) - взброс с аз. пад. $200^{\circ} \angle 61^{\circ}$ и амплитудой по падению 40 см, взбрасывается прослой с аз. пад. $150-165^{\circ} \angle 28^{\circ} ;$ над взбросом выше слой пластически деформирован, а смещенный блок сдвинут по листрическому сбросу с аз. пад. $225^{\circ} \angle 25^{\circ}$; (б) - серия взбросов с аз. пад. $200^{\circ} \angle 78^{\circ}$ и амплитудой по падению до 25 см; (в) - взбросовая зона трещиноватости (ЗТ) с аз. пад. $200^{\circ} \angle 60^{\circ}$ мощностью 15 м, смещенная по ЗТ мощностью 1 м, аз. пад. 3 Т $225^{\circ} \angle 25^{\circ}$, штрихи скольжения по падению.

Fig. 15. Reverse and normal fault displacements of bard tuff in redbrick-colour tuffaceous sandstones of the Early Cretaceous (rocks of the associated kimberlite 'anomaly'), respectively corresponding to stages 5 and 6 in the evolution of the crustal stress state in the Catoca kimberlite pipe area, OP CAT1203: (a) - reverse fault, dip az. $200^{\circ} \angle 61^{\circ}$, dip amplitude of $40 \mathrm{~cm}$, reversed layer with dip.az. $150-165^{\circ} \angle 28^{\circ}$; the layer above the reverse fault is plastically deformed, and the displaced block is shifted along the lustric fault, dip az. $225^{\circ} \angle 25^{\circ}$; (б) - series of reverse fault, dip az. $200^{\circ} \angle 78^{\circ}$, dip amplitude up to $25 \mathrm{~cm}$; ( 8$)$ - reverse fracture zone, dip az. $200^{\circ} \angle 60^{\circ}, 15 \mathrm{~m}$ wide, displaced along the $1 \mathrm{~m}$ wide fracture zone, dip az. $225^{\circ} \angle 25^{\circ}$, striations along the dip.

разнообразия их ориентировки (рис. 14, в). Однако в докембрийских породах имеются смещения маркеров правовзбросо-сдвигового и правосдвигового типа с аз. пад. $55^{\circ} \angle 65^{\circ}$ в т.н. САТ0405 и $67^{\circ} \angle 85^{\circ}$ в т.н. САТ 1301, соответственно, которые укладываются в этап северо-восточного сжатия. Его существование в постраннемеловое время несомненно и подтверждается взбросами, простирающимися на 290-300, и складками в кимберлитах, оси которых склоняются на $290-310^{\circ}$ (рис. $14,2-e$, см. рис. $8, e$; рис. 15).

\section{6. ШЕСТОЙ эТАП}

Последний из реконструированных этапов связан с горизонтальным растяжением в доминирую- щем север-северо-восточном направлении. Согласно коэффициенту $\mathrm{R}=0.19$, определяющему форму эллипсоида напряжений, режим деформирования по штрихам скольжения в кимберлитах определяется как радиальное растяжение со склонением $\sigma_{1}=205^{\circ} \angle 5^{\circ}$ и $\sigma_{2}=298^{\circ} \angle 34^{\circ}$ (рис. 16, a). Этот этап наиболее выражен в кимберлитах, а соответствующее решение характеризуется наилучшим качеством по сравнению с другими стресс-тензорами. Взаимосвязанные следы смещений присутствуют во всех разновидностях кимберлитов. С этим этапом связано формирование листрических сбросов с аз. пад. $225^{\circ} \angle 25^{\circ}$ в т.н. САТ1203, смещающих взбросы с аз. пад. $200^{\circ} \angle 60^{\circ}$ в кимберлитовых туфобрекчиях на предыдущем этапе развития земной коры (см. рис. 15), а также сбросовой зоны интенсивной 


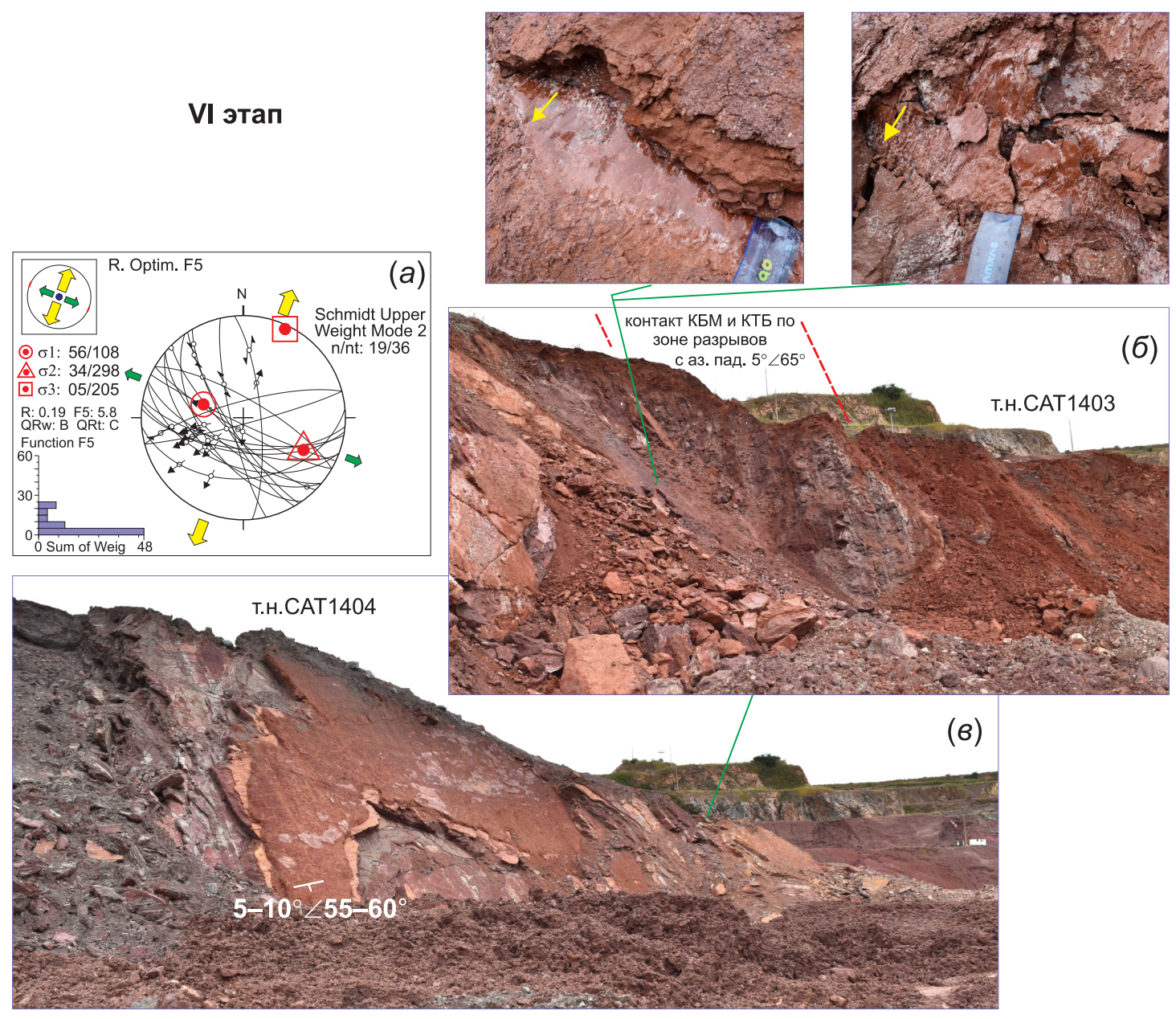

Рис. 16. Геолого-структурные доказательства VI этапа радиального, преимущественно север-северо-восточного, растяжения в кимберлитах и породах комплекса ВОП раннемелового возраста: $(a)$ - реконструкция стресс-тензора по штрихам скольжения (1-е по значимости решение по совокупности данных в кимберлитах и ВОП); (б) - сбросовая зона трещиноватости, дробления и рассланцевания с аз. пад. $5^{\circ} \angle 65^{\circ}$, мощностью 8 м, маркирующая контакт между серо-зелеными КБМ и КТБ кирпичного цвета; контакт проходит через зону вишневых кимберлитов, в которых множество кальцитовых прожилков, по трещинам зеркала скольжения со штрихами по падению (на фото выше), т.н. САТ1403; (в) - крупнейший скол и зона дробления, рассланцевания и трещиноватости с аз. пад. 5-10 $\angle 55-60^{\circ}$, мощностью 4 м (мощность глинки трения - 0.15 м) в аргиллитах и туфопесчаниках комплекса ВОП; к разломной зоне приурочен контакт между ВОП и КБМ, наблюдавшийся севернее за разломной плоскостью (на фото не видно).

Fig. 16. Geostructural evidence of stage 6 (radial, mainly N-NE extension in the Early Cretaceous kimberlite and volcanicsedimentary rocks): $(a)$ - stress tensor reconstructed from striations (the $1^{\text {st }}$ most significant solution from the database on kimberlite and volcanic-sedimentary rocks); (б) - zone of normal fracturing, crushing and schistosity, dip az. $5^{\circ} \angle 65^{\circ}$, width of $\sim 8 \mathrm{~m}$; this zone marks the contact between gray-green massive kimberlite breccias (MKB) and redbrick-colour kimberlitic tuff breccias (KTB); the contact goes through the cherry-colour kimberlite zone containing numerous calcite veins, along the fractures on the slickenside with striations along the dip (see the photo above), OP CAT1403; ( 8$)$ - the largest rock chip and the zone of crushing, schistosity and fracturing, dip az. $5-10^{\circ} \angle 55-60^{\circ}$, width of $\sim 4 \mathrm{~m}$ (the gouge width is $0.15 \mathrm{~m}$ ) in argillites and tuff sandstones of the volcanic-sedimentary rock complex; the contact between the volcanic-sedimentary rocks and the MKB, observed northward beyond the fault plane, is confined to the fault zone (not visible in the photo).

трещиноватости, дробления и рассланцевания с аз. пад. $5^{\circ} \angle 65^{\circ}$, мощностью около 8 м, маркирующей контакт между серо-зелеными массивными кимберлитами и кимберлитовыми туфобрекчиями кирпичного цвета в т.н. САТ1403 (рис. 16, б).

В описываемый этап в гнейсах, в т.н. САТ2005, произошло формирование сбросо-сдвиговой зоны рассланцевания, дробления и милонитизации с аз. пад. $350^{\circ} \angle 80^{\circ}$, вертикальной амплитудой смещения около 5 м и сдвиговыми (правый сбросо-сдвиг) штрихами скольжения, склоняющимися под углом $20^{\circ}$ на плоскости главного сместителя (рис. $17, a$ ). Сдвиговая величина смещения, исходя из геометрических соображений, должна быть еще значи- 


\section{VI этап}

(локальные вариации поля напряжений)
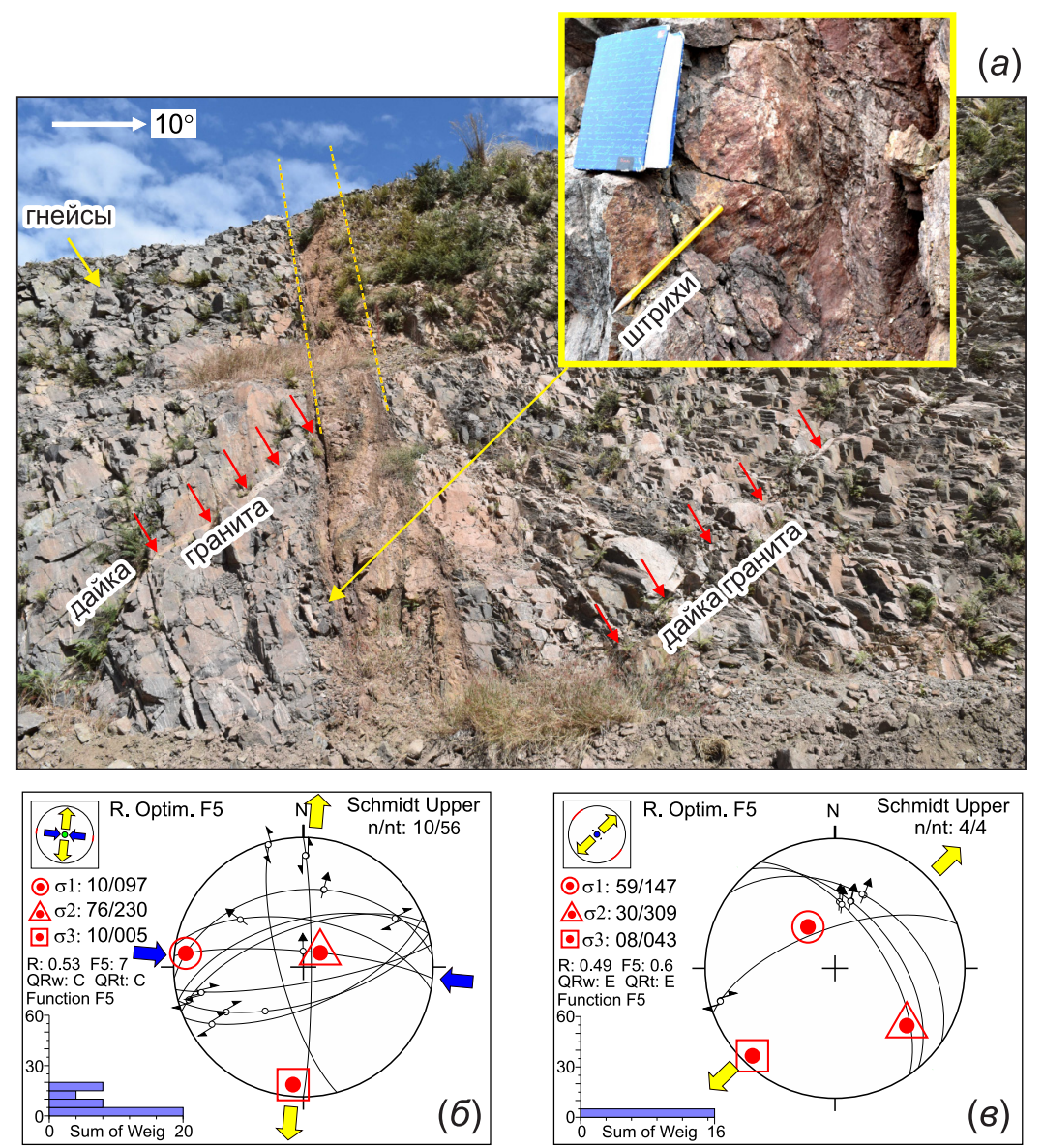

Рис. 17. Зона рассланцевания, дробления и милонитизации (аз. пад. $350^{\circ} \angle 80^{\circ}$, штр. скл. $\left.80^{\circ} \angle 20^{\circ}\right)$ в гнейсах $(a)$; по зоне смещена дайка гранита (аз. пад. 210 $\angle 40^{\circ}$ ) мощностью 5-10 см с вертикальной сбросовой амплитудой 5 м, т.н. САТ2005; реконструкции стресс-тензоров по штрихам скольжения в гнейсах, отражающие локальные вариации поля напряжений на VI этапе: (б), (в) - 3-е по значимости решение по совокупности данных для гнейсов (б), для т.н. САТ0906 (в).

Fig. 17 (a) - zone of schistosity, crushing and mylonitization (dip az. $350^{\circ} \angle 80^{\circ}$, striations $80^{\circ} \angle 20^{\circ}$ ) in gneiss; the granite dike is displaced along this zone (dip az. $210^{\circ} \angle 40^{\circ}$ ), its width is $5-10 \mathrm{~cm}$, vertical normal shear amplitude of $\sim 5.0 \mathrm{~m}$, OP CAT2005. Top - stress tensors reconstructed from striations in gneiss, reflecting local variations of the stress field at stage 6: (б) - the $3^{\text {rd }}$ most significant solution from the database on gneiss; $(\theta)$ - solution for OP CAT0906.

тельнее. Эта самая молодая из наблюденных разломных зон в гнейсах карьера приурочена к древней зоне пластического течения, дробления и трещиноватости с аз. пад. $330^{\circ} \angle 85^{\circ}$ и мощностью около 5 м. Близкое решение, полученное из общей совокупности замеров штрихов скольжения в гнейсах, соответствует сдвиговому режиму деформирования с север-северо-восточным простиранием $\sigma_{3}=5^{\circ} \angle 10^{\circ}$ (рис. 17, б), а в т.н. САТ0906 режим деформирования относится к чистому растяжению в северо-восточном направлении (рис. 17, в). Мы полагаем, что все эти стресс-тензоры отражают флуктуации поля напряжений, при котором ведущим является растяжение в север-северо-восточном направлении. Время этого этапа предполагает- ся позднекайнозойское. Косвенно об этом свидетельствует кулисообразное под правый сдвиг строение гравитационных разрывов на участке сдвижения борта карьера в зоне разлома с аз. пад. $330-340^{\circ} \angle 55-70^{\circ}$, наблюдавшейся в уступе между горизонтами +840 и +860 м (рис. 18), а также правосторонние смещения русла р. Лова с западной стороны карьера.

\section{5. ТЕКТОНИЧЕСКАЯ ИНТЕРПРЕТАЦИЯ И ОБСУЖДЕНИЕ РЕЗУЛЬТАТОВ}

Полученные результаты исследований расширяют наши знания о тектоническом развитии и 


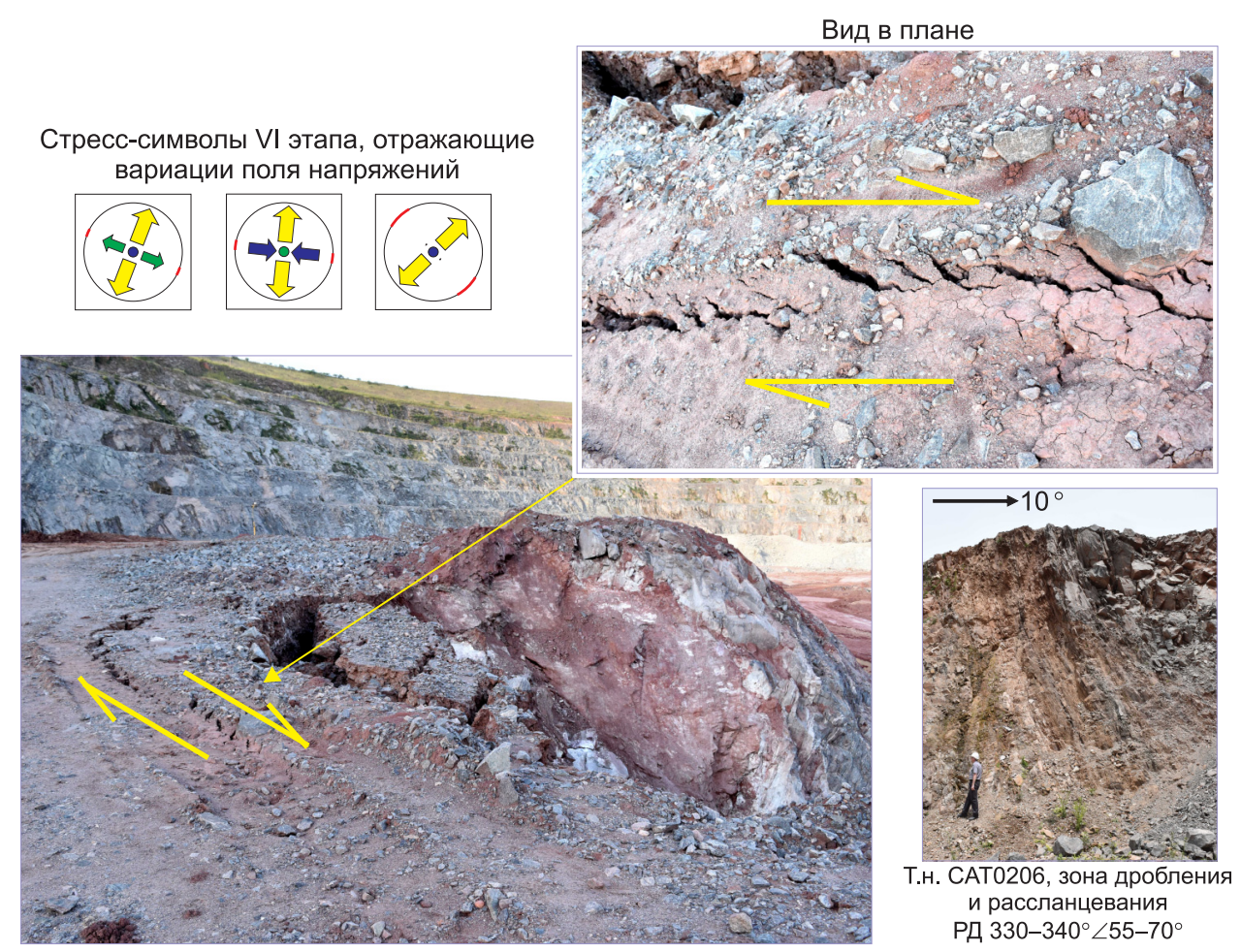

Рис. 18. Сдвижение борта карьера в зоне разлома восток-северо-восточного простирания в т.н. САТ0206. В правом верхнем углу - кулисообразное под правый сдвиг строение гравитационных разрывов. Деформации могут реализоваться только при север-северо-восточном направлении оси горизонтального растяжения, что соответствует VI этапу эволюции напряженного состояния земной коры на карьере трубки Катока.

Fig. 18. Shearing of the quarry side in the E-NE-striking fault zone, OP CAT0206. Upper right-side corner - array of gravitational fractures underneath the right-side strike-slip fault. Such deformation is feasible only in case of the N-NE-trending horizontal extension axis, which corresponds to stage 6 in the evolution of the crustal stress state of the Catoca pipe quarry.

эволюции напряженного состояния земной коры южной части кратона Конго, в которой локализуется трубка Катока. Очевидно, что до начала первого из установленных этапов, который маркируется конформными гнейсовидности крутопадающими и наклонными дайками, были другие деформационные события, о чем свидетельствуют зоны пластического течения и лейкосома в мигматизированных гнейсах и амфиболитах, подчеркивающая нередко изоклинальную складчатость толщи. Эти события, исходя из залегания метаморфических пород (см. рис. 5), отражают пластические условия деформирования земной коры при сжатии в направлении 320-350.

Внедрение согласных с гнейсовидностью даек первого задокументированного этапа в режиме растяжения со сдвигом происходило уже в более «холодных» хрупкопластичных условиях, о чем свидетельствуют их относительно ровные борта, часто подчеркнутые разрывами, и заметное увеличение мощности гранитных интрузий. Этот этап можно было бы связать с растяжением на южном окончании кратона Конго, начало которого отно- сят к временной границе 880-870 млн лет назад и ассоциируют с распадом Родинии [John et al., 2004], но общепринятый архейский возраст пород щита Касаи не позволяет это сделать.

Последующие этапы тектонического развития также связаны с процессами, происходившими и продолжающимися в подвижных поясах Южной и Центральной Африки. Как уже упоминалось, второй этап северо-западного сжатия может быть ассоциирован с континентальной коллизией между кратонами Конго и Калахари, завершившейся к началу кембрия - 530 млн лет назад [John et al., 2004]. Эта коллизия стала продолжением конвергенции этих плит, при которой океаническая литосфера с северной стороны (в современных координатах) субдуцировала с образованием эклогитов 600 млн лет назад [John et al., 2003]. Все эти деформационные события относятся к панафриканскому орогенезу, связанному с образованием Гондваны, в ходе которого последний раз была переработана и сформирована континентальная кора Африканского континента [John et al., 2004]. Поскольку следы второго этапа мы наблюдаем и в пластических, и в 
разрывных деформациях (см. рис. 9 и 10) даже внутри платформы, следует согласиться с предположением Л. Кипата и его соавторов, что этап сжатия в Луфилианском поясе - одном из сегментов орогенного пояса между кратонами Конго и Калахари - можно разделить на две стадии: раннюю пластическую или хрупкопластическую (более вероятно) и позднюю разрывную [Kipata et al., 2013]. В цитированной работе первый этап субмеридионального сжатия, охватившего всю Луфилианскую дугу, ассоциируется с установленным нами вторым этапом северо-западного сжатия (некоторые замеры шарниров складок также показывают сжатие с юга на север, см. рис. 9, г). Отличие в ориентировке сжимающих напряжений объясняется генерализованным близширотным простиранием Луфилианского орогена. Сменяющий его на юго-западе Дамарский складчатый пояс имеет северо-восточное направление, предполагающее северо-западное сжатие (см. рис. 1), господствовавшее там в период 555-550 млн лет назад [Goscombe et al., 2017]. Участок наших исследований находится на удалении 500-700 км от ближайших границ этих панафриканских подвижных систем. Одинаковые геодинамические режимы и схожие направления горизонтальных сжимающих напряжений внутри орогенных поясов и кратона свидетельствуют о возможности передачи напряжений на многие сотни километров в глубь древних платформ, что очень важно при поиске источников активности разломов во внутриплитных обстановках.

Важнейшие для кимберлитообразования третий и четвертый этапы эволюции напряженного состояния земной коры района трубки Катока, по нашему мнению, связаны с открытием центрального сегмента Южной Атлантики. Основное коровое растяжение происходило здесь между берриасским (145.0-139.8 млн лет) и барремским (129.4-125.0 млн лет) ярусами нижнего мела до момента разрыва анголо-бразильского сегмента Гондваны вдоль узкой зоны в аптское время (125-113 млн лет) [Reston, 2010]. При этом большая часть магматических пород была извержена в готеривско-барремское время, что также подтверждается наличием роев толеитовых даек на юго-востоке Бразилии с ${ }^{40} \mathrm{Ar} /{ }^{39} \mathrm{Ar}$ возрастом 129.4-130.6 млн лет [Deckart et al., 1998]. Возраст кимберлитов трубки Катока 118.3 \pm 3.7 млн лет [Robles-Cruz et al., 2010] показывает, что они образовались как раз во время окончательного отделения Африки от Южной Америки. Таким образом, корреляция известных возрастов подтверждает наши предположения о том, что сначала в регионе был мощный этап северо-западного растяжения (третий этап), поспособствовавший разрыву земной коры на платформе и внедрению основной порции кимберлитовой магмы. Впослед- ствии во внутриконтинентальной обстановке кратона Конго он сменился на геодинамический режим сдвига (четвертый этап).

Трудно сказать, была ли активизация региональных разломов «коридора Лукапа» в верхнем палеозое, как считает В.Н. Зинченко [Zinchenko, 2015], но действительно в период 180-350 млн лет назад, в позднем палеозое - раннем мезозое, в бассейне Конго был первый и наиболее заметный период опускания, который совпал с началом главного карбон-пермского оледенения Гондваны [Linol et $a l ., 2015]$. Это опускание цитируемые авторы объяснили флексурной нагрузкой континентальной литосферы Гондваны, связанной с формированием орогенов в ходе амальгации Пангеи. Очевидно, впадина Конго испытывала тогда пассивное растяжение. Таким образом, временем наибольшей активизации региональных разломов «коридора Лукапа», вероятно, все же следует считать берриасбарем, а также апт.

По-видимому, пятый этап северо-восточного сжатия начался практически сразу после внедрения кимберлитов и накопления вулканогенноосадочных отложений, которые еще сохраняли пластические свойства на локальных участках. Об этом свидетельствуют интенсивные складчатые деформации раннемеловых пород комплекса ВОП (см. рис. 7, e; рис. 14). Заключение о времени проявления данного этапа согласуется с представлениями В.Н. Зинченко [Zinchenko, 2015], отмечавшего инверсию авлакогена в посткимберлитовое время $\left(\mathrm{K}_{2}-\mathrm{N}\right)$, которая носила блоковый характер с движениями по разломам, поперечным древним структурам. В результате на северо-восточном фланге «коридора Лукапа» к началу кайнозойской эры сформировалось высокое плато с пологим рельефом и отметками более 1000 м. В работе [Linol et al., 2015] на основе данных стратиграфии и бассейнового анализа впадины Конго также делается заключение о нескольких эпизодах воздыманий данной территории, одно из которых по времени близко к позднемеловому эпейрогенезу плато Калахари [De Wit, 2007], а второе произошло в палеогене 30-50 млн лет назад и привело к возникновению Ангольского куполовидного поднятия [Walford, White, 2005; Pik et al., 2008] юго-западнее трубки Катока. Причину этих воздыманий цитируемые авторы связывают с формированием крупных изверженных провинций и началом континентального рифтогенеза в Восточно-Африканской рифтовой системе. В этом случае единственное объяснение северо-восточного сжатия, возникшего в глубине платформы, видится в отклике интенсивных восходящих движений, которые происходили на начальном этапе рифтогенеза в югозападном плече Танганьикского рифта, располо- 
женного в 1050 км от трубки Катока и имеющего север-северо-западное простирание.

Хорошо выраженный в хрупких деформациях последний этап, выделенный на основе геологоструктурных данных по трубке Катока, коррелирует с седьмой стадией, характеризующейся северсеверо-восточным и северо-восточным растяжением, господствующей в кайнозое в Луфилианском поясе, в районе озер Руква, Мверу и южного окончания озера Танганьика [Kipata et al., 2013]. Цитируемые авторы связывают этот этап деформаций с развитием разломов, близких по направлению к Танганьикскому рифту. На трубке Катока данное поле напряжений реализуется в сбросовых и сдвиговых подвижках по трещинам схожего северсеверо-западного и северо-западного направлений, а также по разрывам запад-северо-западного и восток-северо-восточного простирания (см. рис. 16). Такая корреляция подобных по типу стресс-тензоров в различных регионах Южной Африки свидетельствует о региональном уровне поля напряжений с горизонтальным север-северо-восточным и северо-восточным растяжением. Однако, если для района трубки Катока это последний этап деформаций по имеющимся на сегодняшний день данным, то для большей части Южной Африки, по данным о механизмах очагов землетрясений [Delvaux, Barth, 2010] и по результатам моделирования методом конечных элементов [Bird et al., 2006], современное поле напряжений характеризуется северозападным растяжением, включая Луфилианскую дугу и окрестности, но не южное окончание Танганьикского рифта и восточное побережье Атлантики. В ближайших к трубке Катока трех очагах землетрясений ось сжатия имеет субширотное простирание [Delvaux, Barth, 2010], что предполагает субмеридиональное растяжение. При этом все три механизма имеют разный тип: взбросовый, сбросовый и сдвиговый. Аналогичная ориентировка главных осей напряжений по данным моделирования получена для западных берегов Южной Африки и прилегающей части Атлантического океана между 15 и $5^{\circ}$ ю.ш. и 5 и $13^{\circ}$ в.д., а тип поля напряжений трансформируется от сдвигового в океанической коре до сбросового в материковой [Bird et al., 2006, Fig. 7]. Подобие полей напряжений как по типу, так и по ориентировке главных осей напряжений в земной коре района трубки Катока, юга Танганьикского рифта и восточного побережья Атлантики определенно свидетельствует о сильном влиянии геодинамических процессов, происходящих на активных границах плит, на напряженное состояние в глубине древних платформ. В качестве возможного механизма передачи тектонических напряжений в таком случае можно предположить волновой процесс - распространение колебаний в среде, которо- му посвящено множество современных публикаций (см. обзор в работе [Sherman, 2013]).

\section{6. ЗАКЛЮЧЕНИЕ}

Первые результаты геолого-структурных и тектонофизических исследований раннемеловой кимберлитовой трубки Катока и вмещающих пород докембрийского возраста позволили сделать следующие основные выводы:

1. В эволюции напряженного состояния земной коры юго-западного фланга щита Касаи на северовостоке Анголы выделяется как минимум шесть основных этапов регионального масштаба. Эти этапы определяются доминированием ориентированных в определенном направлении горизонтальных тектонических напряжений сжатия и/или растяжения, господствовавших в течение всей истории тектонического развития региона.

2. По соотношению хрупких и пластических деформаций в разновозрастных вмещающих породах и кимберлитовых формациях определена последовательность проявления разных геодинамических режимов. В ходе первого этапа северо-западного растяжения со сдвигом и начала второго этапа северо-западного сжатия формирование структур во вмещающих породах происходило в хрупкопластических условиях. Смена пластических деформаций на разрывные могла произойти примерно 530-510 млн лет назад, когда континентальная кора Африки в ходе панафриканского орогенеза была уже окончательно сформирована. Третий и четвертый этапы, важнейшие для кимберлитообразования, в ходе которых в раннем мелу радиальное растяжение сменилось сдвиговым полем напряжений, характеризуются превалированием северо-западного растяжения. Оба этапа связаны с открытием центрального сегмента Южной Атлантики, а основной кимберлитовый магматизм приходится на момент разрыва анголо-бразильского сегмента Гондваны.

3. В ходе первых четырех этапов разрядка напряжений происходила по разрывам северо-восточного и восток-северо-восточного простирания, в меньшей степени северо-западного и широтного. Начальный этап кимберлитового магматизма, определяемый по внедрению маломощных даек, связан с разрывами двух первых направлений, что изначально определено наличием докембрийских зон течения и рассланцевания, которые оказались наиболее благоприятными для реализации северозападного субгоризонтального растяжения.

4. Два последних посткимберлитовых этапа совершенно изменили план деформаций. Последующее северо-восточное сжатие, начавшееся во второй половине мела и, возможно, продлившееся до 
конца палеогена, реализовалось в основном по разрывам северо-западного простирания. В региональном отношении ему соответствуют две стадии инверсионных движений на юге Африке [Linol et al., 2015]. Последний этап горизонтального растяжения в доминирующем север-северо-восточном направлении связан с процессами, происходящими на юге Танганьикского рифта и восточном побережье Атлантики.

5. Корреляция особенностей поля напряжений в земной коре района трубки Катока, установленных для разных временных периодов, с имеющимися сведениями для других регионов Южной Африки свидетельствует о сильном влиянии геодинамических процессов, происходящих на активных границах плит, на напряженное состояние в глубине древних платформ.

Результаты исследований позволили получить представление об основных этапах развития ре- гиона, которые впоследствии будут уточняться на основании большего количества измерений тектонических деформаций и штрихов скольжения, а также данных датирования вмещающих пород.

\section{7. БЛАГОДАРНОСТИ}

Полевые исследования выполнялись в рамках сотрудничества между ИЗК СО РАН и Департаментом геологии ГРО CATOKA LTD. Авторы благодарны геологам Департамента геологии ГРО CATOKA LTD за помощь в организации полевых работ. Результаты реконструкций стресс-тензоров получены с помощью программы "Win-Tensor" версии 5.8.6, разработанной Д. Дельво из Королевского музея Центральной Африки, Тервюрен, Бельгия.

\section{8. ЛИТЕРАTУРA / REFERENCES}

Angelier J., 1979. Determination of the mean principal direction of the stress for a given fault population. Tectonophysics 56 (3-4), T17-T26. https://doi.org/10.1016/0040-1951(79)90081-7.

Araujo A., Guimaraes F., Perevalov O. et al., 1992. Geologia de Angola. Nota explicativa da Carta Geologica a escala 1:1000000. Luanda, S.G.A., 137 p.

Araujo A., Perevalov O., Guimaraes F. et al., 1998. Republica de Angola. Carta de recursos minerais, 1:1000000. Luanda, Instituto Geologico de Angola.

Bird P., Ben-Avraham Z., Schubert G., Andreoli M., Viola G., 2006. Patterns of stress and strain rate in southern Africa. Journal of Geophysical Research: Solid Earth 111 (B8), B08402. https://doi.org/10.1029/2005JB003882.

Bosworth W., 2008. North Africa-Mediterranean Present-day Stress Field Transition and Implications for Fractured Reservoir Production in the Eastern Libyan Basins. Geology of East Libya 4, 123-138.

De Boorder H., 1982. Deep-reaching fracture zones in the crystalline basement surrounding the West Congo System and their control of mineralization in Angola and Gabon. Geoexploration 20 (3-4), 259-273. https://doi.org/ 10.1016/0016-7142(82)90025-4.

De Wit M.J., 2007. The Kalahari epeirogeny and climate change: differentiating cause and effect from core to space. South African Journal of Geology 110 (2-3), 367-392. https://doi.org/10.2113/gssajg.110.2-3.367.

Deckart K., Féraud G., Marques L., Bertrand, 1998. New time constraints on dyke swarms related to the ParanáEtendeka magmatic province, and subsequent South Atlantic opening, southeastern Brazil. Journal of Volcanology and Geothermal Research 80 (1), 67-83. https://doi.org/10.1016/S0377-0273(97)00038-3.

Delvaux D., 1993. The TENSOR program for reconstruction: examples from east African and the Baikal rift system. Terra Nova 5, 216

Delvaux D., 2001. Tectonic and palaeostress evolution of the Tanganyika-Rukwa-Malawi rift segment, East African Rift System. In: P.A. Ziegler, W. Cavazza, A.H.F. Robertson, S. Crasquin-Soleau (Eds.), Peri-Tethys Memoir 6: PeriTethyan Rift/Wrench Basins and Passive Margins. Mémoires du Muséum national d'histoire naturelle, vol. 186, p. 545-567.

Delvaux D., 2012. Release of program Win-Tensor 4.0 for tectonic stress inversion: statistical expression of stress parameters. Geophysical Research Abstracts 14, EGU2012-5899. Available from: https://meetingorganizer. copernicus.org/EGU2012/EGU2012-5899.pdf.

Delvaux D., Barth A., 2010. African stress pattern from formal inversion of focal mechanism data. Tectonophysics 482 (1-4), 105-128. https://doi.org/10.1016/j.tecto.2009.05.009.

Delvaux D., Sperner B., 2003. Stress tensor inversion from fault kinematic indicators and focal mechanism data: the TENSOR program. In: D.A. Nieuwland (Ed.), New insights into structural interpretation and modelling. Geological Society, London, Special Publications, vol. 212, p. 75-100. https://doi.org/10.1144/GSL.SP.2003.212.01.06.

Ganga J., Nossyko S., Zintchenko V. et al., 2003. Geologia e Genese da Chaminé Quimberlitica de Catoca (Segundo dados modernos de prospecção). Rev. Angola Minas 14 (1 trim), 23-29. 
Gladkov A.S., Koshkarev D.A., Cheremnykh A.V., João F., Karpenko M.A., Marchuk M.V., Potekhina I.A. 2016. Structuralcompositional model of the Nyurbinskaya kimberlite pipe formation (Sredne-Markha area of the Yakutian diamondiferous province). Geodynamics \& Tectonophysics 7 (3), 435-458. https://doi.org/10.5800/GT-2016-7-30216.

Gladkov A.S., Makovchuk I.V., Lunina O.V., Bornyakov S.A., Potekhina I.A., 2010. The Yubileinaya kimberlite pipe site, Russia: 3D model of the fault-block structure. Geology of Ore Deposits 52 (3), 234-251. https://doi.org/10.1134/ S1075701510030049.

Goscombe B., Foster D.A., Gray D., Wade B., Marsellos A., Titus J., 2017. Deformation correlations, stress field switches and evolution of an orogenic intersection: The Pan-African Kaoko-Damara orogenic junction, Namibia. Geoscience Frontiers 8 (6), 1187-1232. https://doi.org/10.1016/j.gsf.2017.05.001.

Gushchenko O.I., 1979. The method of kinematic analysis of destruction structures in reconstruction of tectonic stress fields. In: A.S. Grigoriev, D.N. Osokina (Eds.), Fields of stress and strain in the lithosphere. Nauka, Moscow, p. 7-25 (in Russian) [Гущенко О.И. Метод кинематического анализа структур разрушения при реконструкции полей тектонических напряжений // Поля напряжений и деформаций в литосфере / Ред. А.С. Григорьев, Д.Н. Осокина. М.: Наука, 1979. С. 7-25].

John T., Schenk V., Haase K., Scherer E., Tembo F., 2003. Evidence for a Neoproterozoic ocean in south-central Africa from mid-oceanic-ridge-type geochemical signatures and pressure-temperature estimates of Zambian eclogites. Geology 31 (3), 243-246. https://doi.org/10.1130/0091-7613(2003)031\%3C0243:EFANOI\%3E2.0.CO;2.

John T., Schenk V., Mezge K., Tembo F., 2004. Timing and PT evolution of Whiteschist metamorphism in the Lufilian Arc-Zambezi Belt Orogen (Zambia): Implications for the Assembly of Gondwana. The Journal of Geology 112 (1), 71-90. https://doi.org/10.1086/379693.

Kipata M.L., Delvaux D., Sebagenzi M.N., Cailteux J., Sintubin M., 2013. Brittle tectonic and stress field evolution in the Pan-African Lufiian arc and its foreland (Katanga, DRC): from orogenic compression to extensional collapse, transpressional inversion and transition to rifting. Geologica Belgica 16 (1-2), 1-17.

Linol B., de Wit M.J., Guillocheau F., Robin C., Dauteuil O., 2015. Multiphase Phanerozoic subsidence and uplift history recorded in the Congo Basin: a complex successor basin. In: M.J. de Wit, F. Guillocheau, M.C.J. de Wit (Eds.), Geology and resource potential of the Congo Basin. Springer-Verlag, Berlin, Heidelberg, p. 213-227. https://doi.org/ 10.1007/978-3-642-29482-2_11.

Mankenda A., 1989. Geology of Diamond Deposits in the Northeastern Angola. Brief PhD Thesis (Candidate of Geology and Mineralogy). Moscow, 25 p. (in Russian) [Манкенда А. Геология месторождений алмазов северо-востока Анголы: Автореф. дис. ... канд. геол.-мин. наук. М., 1989. 25 с.].

Meghraoui M. and the IGCP-601 Working Group, 2016. The Seismotectonic Map of Africa. Episodes 39 (1), 9-18.

Parfeevets A.V., San'kov V.A., 2006. Stress State of the Earth's Crust and Geodynamics of the Southwestern Part of the Baikal Rift System. Geo Academic Publishing House, Novosibirsk, 151 p. (in Russian) [Парфеевец А.В., Саньков B.A. Напряженное состояние земной коры и геодинамика юго-западной части Байкальской рифтовой системы. Новосибирск: Академическое изд-во «Гео», 2006. 151 с.].

Pik R., Marty B., Carignan J., Yirgu G., Ayalew T., 2008. Timing of East African Rift development in southern Ethiopia: Implication for mantle plume activity and evolution of topography. Geology 36 (2), 167-170. https://doi.org/ 10.1130/G24233A.1.

Reis B., 1972. Preliminary note on the distribution and tectonic controls of kimberlites in Angola. In: 24th International Geological Congress, Montreal, Section 4, p. 276-281.

Reston T.J., 2010. The opening of the central segment of the South Atlantic: symmetry and the extension discrepancy. Petroleum Geoscience 16 (3), 199-206. https://doi.org/10.1144/1354-079309-907.

Robles-Cruz S., Escayola M., Davis B. et al., 2010. The first SHRIMP U-Pb zircon ages from Catoca and Tchiuzo kimberlites, Angola. VII SSAGI South American Symposium on Isotope Geology, Brasília, 25 $5^{\text {th }}-28^{\text {th }}$ July 2010, 5 p.

Serokurov Yu.N., 2006. Possibilities of remote sensing materials for allocating areas promising for the search for kimberlites. Otechestvennaya Geologia (Russian Geology) (3), 6-11 (in Russian) [Серокуров Ю.Н. Возможности материалов дистанционного зондирования при выделении площадей, перспективных для поисков кимберлитов // Отечественная геология. 2006. № 3. С. 6-11].

Serokurov Yu.N., Kalmykov V.D., 2004. The image of the Catoca kimberlite field (Angola) in remote sensing materials. Rudy i Metally (Ores and Metals) (5), 5-8 (in Russian) [Серокуров Ю.Н., Калмыков В.Д. Образ кимберлитового поля Катока (Ангола) в материалах дистанционного зондирования // Руды и металлы. 2004. № 5. С. 5-8].

Sherman S.I., 2013. Deformation waves as a trigger mechanism of seismic activity in seismic zones of the continental lithosphere. Geodynamics \& Tectonophysics 4 (2), 83-117 (in Russian) [Шерман С.И. Деформационные волны как триггерный механизм сейсмической активности в сейсмических зонах континентальной литосферы // Геодинамика и тектонофизика. 2013. T. 4. № 2. C. 83-117]. https://doi.org/10.5800/GT-2013-4-2-0093.

Soumaya A., Ayed N.B., Delvaux D., Ghanmi M., 2015. Spatial variation of present-day stress field and tectonic regime in Tunisia and surroundings from formal inversion of focal mechanisms: Geodynamic implications for central Mediterranean. Tectonics 34 (6), 1154-1180. https://doi.org/10.1002/2015TC003895.

Squire R.J., Campbell Y.H., Allen C.M., Wilson C.J.L., 2006. Did the Transgondwanan Supermountain trigger the explosive radiation of animals on Earth? Earth and Planetary Science Letters 250 (1-2), 116-133. https://doi.org/10.1016/ j.epsl.2006.07.032. 
Vunda T.M., 2010. Features of Geology, Material Composition and Prospects of the Lorelei Diamondiferous Kimberlite Pipe (Angola). Brief PhD Thesis (Candidate of Geology and Mineralogy). Dnepropetrovsk, 30 p. (in Russian) [Вунда T.M. Особенности геологии, вещественного состава и перспективы алмазоносности кимберлитов трубки Лорелей (Ангола): Автореф. дис. ... канд. геол.-мин. наук. Днепропетровск, 2010. 30 с.].

Walford H.L., White N.J., 2005. Constraining uplift and denudation of West African continental margin by inversion of stacking velocity data. Journal of Geophysical Research: Solid Earth 110 (B4), B04403. https://doi.org/10.1029/ 2003JB002893.

Wallace R.E., 1951. Geometry of shearing stress and relation to faulting. The Journal of Geology 59 (2), 118-130. https://doi.org/10.1086/625831.

White S.H., de Boorder H., Smith C.B., 1995. Structural controls of kimberlite and lamproite emplacement. Journal of Geochemical Exploration 53 (1-3), 245-264. https://doi.org/10.1016/0375-6742(94)00033-8.

Zinchenko V.N., 2015. Deposits of Diamonds from Kimberlites in Northeastern Angola. PhD Thesis (Doctor of Geology and Mineralogy). St. Petersburg State University, St. Petersburg, 314 p. (in Russian) [Зинченко В.Н. Месторождения алмазов из кимберлитов северо-востока Анголы: Дис. ... докт. геол.-мин. наук. СПб.: Санкт-Петербургский государственный университет, 2015. 314 с.].

Zinchenko V.N., Dulapchy E.V., Félix J.T., Duarte T.D., Vanchugov V.A., 2011. Structural-tectonic control of manifestations of kimberlite magmatism in the northeast of the Republic of Angola. Regional Geology and Metallogeny (47), 107-114 (in Russian) [Зинченко В.Н., Дулапчий Е.В., Феликс Ж.Т., Дуарте Т.Д., Ванчугов В.А. Структурнотектонический контроль проявлений кимберлитового магматизма на северо-востоке Республики Ангола // Региональная геология и металлогения. 2011. № 47. С. 107-114].

Zinchenko V., Félix J.T., Dech V., 2006. Distribuição de diamantes nos kimberlitos de Catoca e os modelos da termodinâmica estatística. Rev. Angola Minas 22 (2-o trim), 20-31.
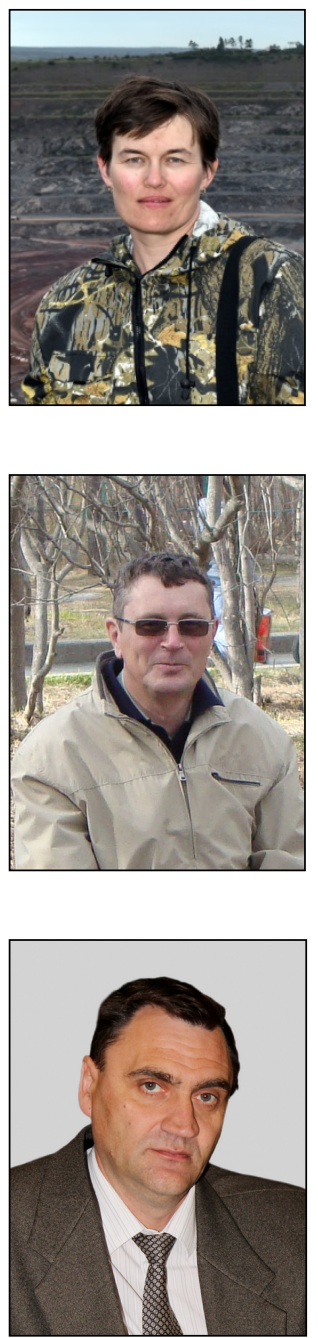

Дмитрий Петрович Гладкочуб, член-корреспондент РАН, докт. геол.-мин. наук, директор института Институт земной коры СО РАН

664033, Иркутск, ул. Лермонтова, 128, Россия

e-mail: dima@crust.irk.ru

ORCID ID https://orcid.org/0000-0001-7227-8253

Dmitry P. Gladkochub, Doctor of Geology and Mineralogy, Corresponding Member of RAS,

Director of the Institute

Institute of the Earth's Crust, Siberian Branch of RAS

128 Lermontov street, Irkutsk 664033, Russia 


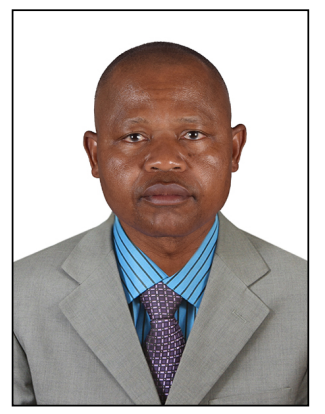

Франциско Жоао, руководитель минералогической лаборатории

Горнорудное общество Катока (ГРО Катока)

Провинция Луанда-Сул, Республика Ангола

e-mail: francisco_joao@catoca.com

Francisco João, Head of the Mineralogical Laboratory

Sociedade Mineira de Catoca (Catoca Ltd.)

Luanda Sector Talatona, Luanda Sul, Angola

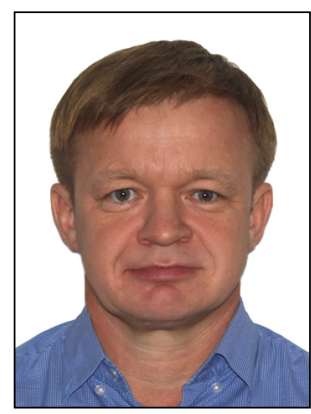

Михаил Анатольевич Карпенко,

Горнорудное общество Катока (ГРО Катока)

Провинция Луанда-Сул, Республика Ангола

e-mail: m.a.k68@mail.ru

\section{Michael A. Karpenko,}

Sociedade Mineira de Catoca (Catoca Ltd.)

Luanda Sector Talatona, Luanda Sul, Angola

\section{Жоао Тунга Феликс}

Горнорудное общество Катока (ГРО Катока)

Провинция Луанда-Сул, Республика Ангола

e-mail: felix@catoca.com

\section{Joao Tunga Felix}

Sociedade Mineira de Catoca (Catoca Ltd.)

Luanda Sector Talatona, Luanda Sul, Angola

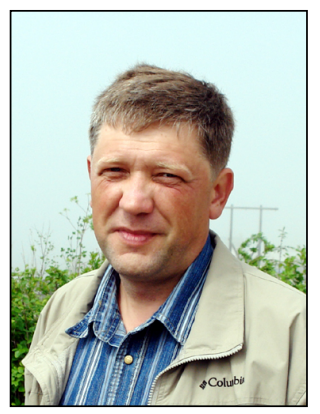

Денис Анатольевич Кошкарев, канд. геол.-мин. наук, заведующий отделом Научно-исследовательское геологоразведочное предприятие АК «АЛРОСА» (ПАО) 678174, Мирный, Чернышевское шоссе, 16, Россия

e-mail: KoshkarevDA@alrosa.ru

Denis A. Koshkarev, Candidate of Geology and Mineralogy, Head of Department Geological Enterprise of Exploration, Public Joint Stock Company «ALROSA» 16 Chernychevskoe highway, Mirny 678174, Russia

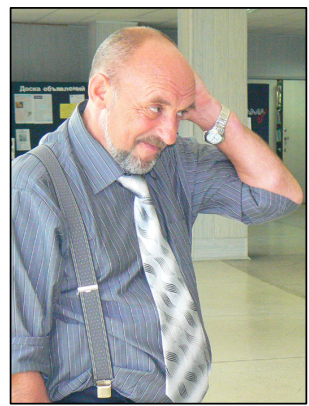

Евгений Викторович Скляров, член-корреспондент РАН, докт. геол.-мин. наук, профессор, г.н.с. Институт земной коры СО РАН

664033, Иркутск, ул. Лермонтова, 128, Россия

e-mail: skl@crust.irk.ru

ORCID ID https://orcid.org/0000-0002-9194-5506

Eugene V. Sklyarov, Corresponding Member of RAS, Doctor of Geology and Mineralogy, Professor, Chief Researcher

Institute of the Earth's Crust, Siberian Branch of RAS

128 Lermontov street, Irkutsk 664033, Russia 